

\author{
UNIVERSIDADE DE BRASÍLIA - UNB \\ INSTITUTO DE CIÊNCIAS HUMANAS - IH \\ DEPARTAMENTO DE SERVIÇO SOCIAL - SER
}

\title{
TRABALHO E EXPLORAÇÃO - CATEGORIAS DE COMPREENSÃO ANÁLOGA PARA AS TRAVESTIS QUE ATUAM NA PROSTITUIÇÃO DO SETOR COMERCIAL SUL EM BRASÍLIA.
}

CINTHYA BARROSO DE SOUSA

Brasília (DF), dezembro de 2008. 
TRABALHO DE CONCLUSÃO DE CURSO

TRABALHO E EXPLORAÇÃO - CATEGORIAS DE COMPREENSÃO ANÁLOGA PARA AS TRAVESTIS QUE ATUAM NA PROSTITUIÇÃO DO SETOR COMERCIAL SUL EM BRASÍLIA.

Trabalho de Conclusão de Curso apresentado para diplomação do curso de Serviço Social na Universidade de Brasília, sob orientação da Prof. ${ }^{\text {a }}$ Patrícia Cristina Pinheiro.

\section{Banca Examinadora:}

Professora Mestre Patrícia Cristina P. de Almeida (orientadora)

Assistente Social Paula Michele Gomes

Professor Doutorando Luiz Fernando Viegas

Brasília (DF), dezembro de 2008. 


\section{INDÍCE ANÁLITICO}

AGRADECIMENTOS …............................................................................................................. 5

RESUMO ................................................................................................................... 6

ACRÔNIMOS ………….................................................................................................................... 7

1- INTRODUÇÃ

1.1 Pergunta de Pesquisa ........................................................................................................... 10

1.2 Hipótese de Pesquisa ..................................................................................................................... 10

1.3 Justificativa ............................................................................................................................. 11

1.3.1 Importância do Estudo no Contexto da Formação como Assistente Social ......... 11

1.3.2 Importância do Estudo em relação ao Conhecimento Científico ........................... 12

1.3.3 Importância do Estudo em relação às Políticas Públicas .......................................... 15

2. REFERENCIAL TEÓRICO....................................................................................... 19

2.1. Categorias norteadoras: Trabalho e Exploração..........................................................19

2.2. História da Homossexualidade.........................................................................................21

2.3. Relatos sobre a Homossexualidade no Brasil ..............................................................26

2.4. Gênero, identidade de gênero, subversão do gênero ……………………………….....29

2.4.1 Travestismo e Travestis ....................................................................................................32

2.5. Breve histórico da Prostituição ........................................................................................36

2.6. Prostituição de travestis ..........................................................................................................40

3. METODOLOGIA …................................................................................................................... 42

3.1 Método....................................................................................................................................... 44

4 APRESENTAÇÃ̃ E ANÁLISE DO OBJETO DE ESTUDO...................................... 46

4.1. Prostituiçãa............................................................................................................................46 
4.2. Prostituição e Exploração..............................................................................................48

4.3. Prostituição e Trabalho.....................................................................................................................51

4.4. Travestis que atuam na Prostituição em Brasília...............................................................53

4.5. O que as travestis pensam da prostituição? É trabalho ou exploração? .................54

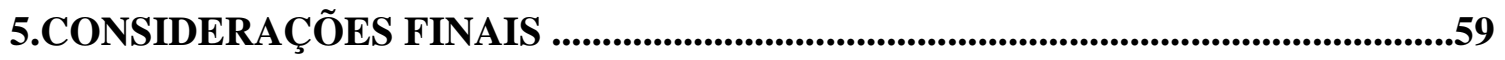

6. REFERÊNCIAS BIBLIOGRÁFICAS ..................................................................61

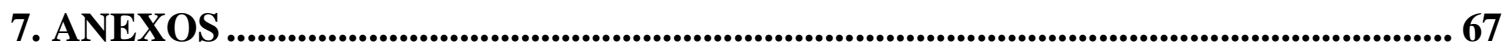

7.1. ANEXO 1 - ROTEIRO DE ENTREVISTA .........................................................67 


\section{AGRADECIMENTOS}

Dedico essa monografia à minha Mãe Rozilania, cearense assim como eu de muita força que destinou sua vida para o crescimento da família, obrigada mãe o meu amor por ti não cabe nem em Saturno. À minha irmã Marília, pelas conversas a fio nos nosso quartos e pelas identificações que as barreiras cronológicas não impuseram, obrigada pelo carinho e a compreensão. Ao meu irmão pelas risadas, espero que você cresça infinitamente e que não perca sua doçura nunca. Ao meu pai por ter me feito íntegra, lutadora, pelos direcionamentos, apoio e respeito.

À Dona Ana nos momentos em que muito precisei foi uma segunda mãe, ao Gilmar pelos papos cósmicos e Camila sempre racional e afetiva esteve disposta a tornar melhores muita momentos difíceis.

Minha amiga querida de Iansã Camila Rosa obrigada por ser extremamente especial, pelos momentos de aventuras, por me escutar tantas vezes e por te ouvir também, te amo muito guria sou muito grata só por você existir. José Higino nas aventuras musicais, por outros olhares antes nunca alcançados, pela ajuda sempre disponível (embora você nunca atenda celular), te trato mal mas te amo.

Agradecimentos especiais também pela verdadeira amizade e paciência da Professora Patrícia Pinheiro que de maneiras muito leves e sorridentes me orientou. À Professora Maria Lúcia (Baiana), que foi muito responsável pelo que sou enquanto pessoa subjetiva e profissional. Professor Mário Ângelo pela simplicidade e braços abertos me fez te admirar muito. Professor Newton Gomes, tenho muito orgulho de termos construído uma amizade que perdura. Professor Luiz Fernando Viegas, sua experiência, irreverência e profissionalismo são definitivamente qualidades preponderantes para o respeito. Paula Michele que sempre foi companheira, pena que não desfrutamos muito disso, muito obrigada pela sua participação nesse trabalho.

Dona da Boca, falar de você definitivamente não cabem palavras que sejam suficientes. Amor infinito, companheirismo desmedido, sinceridade na medida, lealdade presente. Olhando pra trás acho que não existem momentos importantes em que você não esteve.

Às pessoas queridas Tate, Dju, Tatu, Ellen, Suelene e Lipe.

Ao mais recente amigo Jorgito. Muito obrigada pelos ensinamentos no Candomblé, pelas rezas e por me aproximar dos Orixás. Obrigada a minha mãe Oxum, sempre jogando água nos caminhos e a minha outra mãe Iansã que não me deixa desistir.

Às minhas digníssimas e queridas amigas que me ajudaram na concretização desse trabalho. Vocês são fantásticas, ser travesti já me disseram que não é fácil e vocês se posicionam nesse cenário com tanto bom 
humor e tanta propriedade de si que terão o meu mais profundo respeito. Em especial Charlotte da Mata e Sissy Kelly, respectivamente presidente e vice-presidente na Associação do Núcleo de Apoio e Valorização à Vida das Travestis e Transexuais do DF e Entorno (ANAV - Trans).

\section{RESUMO}

Dentre os segmentos dos quais é possível perceber na prostituição, o mais estigmatizado são as travestis/, por questões associadas à homossexualidade, (re)desenvolvimento do corpo e (re) desenhamento de uma nova identidade física, psicológica e subjetiva. O presente trabalho contou com pesquisa de campo, onde foi realizado o recorte para travestis H-M (Homem - Mulher). Homens biológicos que assumem a identidade física e psicológica feminina, que se prostituem no Setor Comercial Sul (SCS) de Brasília. Trabalho e exploração são categorias presentes na compreensão da prostituição e de quem se vê nesse processo. Para análise, admite-se o conceito de trabalho em Marx, partindo do pressuposto que não existe trabalho sem exploração, ou seja, ambas as categorias apesar de percebidas separadas fazem parte do mesmo contexto da sociedade capitalista de exploração. Um dos objetivos do trabalho é remontar a história da homossexualidade e pincelar o surgimento dos movimentos $\mathrm{LGBT}^{1}$, compreender o espaço do transgenderismo e travestismo, desenvolver questões relativas a (re) montagem ou desatrelamento do gênero a partir do biológico e acompanhar o surgimento da prostituição. Todas as categorias para montar o objeto central que é perceber de que maneira as travestis passaram a ser tão expressivas na prostituição e como elas se percebem nesse processo, trabalhadoras ou exploradas?

\section{PALAVRAS-CHAVE:}

Trabalho, Exploração, Prostituição, Homossexualidade, Travestis, Prostituição de Travestis. 


\section{ACRÔNIMOS}

TCC: Trabalho de Conclusão de Curso

SCS: Setor Comercial Sul de Brasília

H -M (Homem - Mulher): Que nasceram homens biológicos e assumem a identidade física e psicológica feminina.

LGBT: Lésbicas, Gays, Bissexuais, Travestis, Transexuais e Transgêneros.

CFESS: Conselho Federal de Serviço Social.

DST: Doenças Sexualmente Transmissíveis.

AIDS: Acquired immune deficiency syndrome, traduzido para o português Síndrome da Imunodeficiência Adquirida.

ANAV - Trans: Associação de Valorização à Vida de Travestis e Transexuais do DF e Entorno. 


\section{INTRODUÇÃO}

A história da prostituição assume diferentes aspectos nas diferentes sociedades em que é exercida, contudo, nesse trabalho ela é entendida a partir do recorte espaço-temporal que circunscreve sociedades ocidentais capitalistas de formação cristã, em que a prostituição é vista num contexto de extrema repressão sexual e rígida expansão da instituição do matrimônio e da idéia de família, fundamentadas pela Igreja Católica (PATEMAN, 1993)

A prostituição se expressa como uma necessidade social. O capitalismo e o que ele traz como consequiências: o urbanismo, a sociedade privada, o mercantilismo, a acumulação de riquezas, o pauperismo, alteram o ritmo natural da vida e necessariamente o das manifestações sexuais. O mercantilismo aproveitou-se disso para negociar e comercializar essa prática. (ROBERTS, 1992)

Partindo do pressuposto de que os serviços sexuais oferecidos na prostituição assumem caráter de mercadoria e por conseqüência produto, o presente trabalho resgata o conceito de mercadoria em (MARX, 1975) colocando que mercadoria é a forma que os produtos assumem quando organizados para finalidade de troca, as mercadorias nesse processo assumem duas formas de poder: valor de uso (finalidade para satisfazer as necessidades humanas) e valor de troca (dimensão quantitativa, a proporção onde valores de uso de determinado tipo são trocados por valores de uso de outro tipo).

Os serviços sexuais são resultantes de uma demanda social por sexo. Em um mercado bem definido quem demanda assume para si o valor de uso e quem oferta toma para si o valor de troca, estabelecendo um paralelo entre uso e consumo. Quem usa consome o produto que é ofertado para satisfação de suas necessidades e quem oferta utiliza a prostituição como valor de troca para a manutenção de sua existência. Sendo assim, podendo se perceber uma relação similar a dos (as) operários (as) que vendem a sua força de trabalho, a prostituta comercializa uma mercadoria/serviço.

A noção de trabalho foi deturpada e o atual panorama que se observa é de extrema exploração onde os vínculos são totalmente distintos. A condição de exploração submete uma legião de trabalhadores (as) à condição irremediável da pobreza em duas esferas: política e de riquezas. Produz um contingente destinado à servidão contemporânea descaracterizando até a 
mesmo a sua existência, transformando esse segmento em servos com laços eternos de servidão. (HOBSBAWM, 1996)

A partir de determinado momento da organização das sociedades, passou a se configurar a exploração de seres por outros seres. Essa exploração ocorreu principalmente pela utilização do trabalho para obtenção de benefícios e através dessa mesma exploração para fins próprios na relação de dependência patrão - empregado, pudemos observar a acumulação de riquezas. (SADER, 1999)

A perspectiva aqui é a de que o trabalho por si só na sociedade no capital, já se caracteriza como explorado, a prostituição assumindo dois níveis de exploração, a econômica e a do ponto de vista da condição humana, onde os serviços sexuais constroem uma teia de submissão dos seres.

O presente trabalho faz o recorte da prostituição de travestis, por entender que se caracteriza um grupo bastante expressivo na atividade, além de ser submetido a uma gama de vulnerabilidades provocadas pela sociedade contra as suas escolhas corporais e sexuais. Levando em consideração o panorama exposto de diversas opressões colocadas como o patriarcado, a homossexualidade, a transição entre os conceitos que permeiam e define gênero, o que se percebe é que as travestis têm assumido funções laborativas subalternizadas, dentre as quais a prostituição, sendo muitas vezes associada à sua figura a essa atividade.

O trabalho pretende discutir conceitos como identidade, metamorfoses e performances de gênero com a finalidade de compreender as relações de estigmatização e opressão às quais as travestis estão inseridas e desse modo identificar de que forma elas se tornaram tão expressivas na atividade da prostituição, nos marcos da historicidade do sistema capitalista atual.

Este Trabalho de Conclusão de Curso (TCC) tem como objetivo realizar uma reflexão acerca das travestis que trabalham como prostitutas no Setor Comercial Sul de Brasília (SCS). Em uma análise que se baseia no desenvolvimento histórico social econômico do capitalismo e que considera o pressuposto de que todas as relações de trabalho inseridas na lógica e na estrutura do capital têm em sua base a exploração, o objetivo é compreender como as travestis se percebem nesse processo, ou seja, investigar a partir de quem vivencia as duas categorias de analise, trabalho e exploração. O objetivo é estender o estudo à realidade, demonstrando que trabalho e exploração, em uma compreensão mais extensa, são categorias distintas. 


\section{1 - Pergunta de Pesquisa:}

Partindo do pressuposto de que trabalho e exploração na sociedade do capital são categorias intrínsecas, as travestis que trabalham oferecendo serviços sexuais no Setor Comercial Sul de Brasília (SCS), percebem a atividade da prostituição como um trabalho ou exploração?

\section{2 - Hipótese de Pesquisa:}

Por ser um segmento que sofre estigmatização, transfobia $^{2}$ e por sua expressão de caráter transgressor e subversivo ao que se define como gênero, as travestis assumem novos comportamentos opostos aos antes ditados de feminino e masculino. Vivenciam novas formas de opressão do corpo, da afetividade e da sexualidade. Na condição de travesti, a moral burguesa não permite a inserção dessas em "empregos" formais ou informais, por conta disso, a prostituição acaba por se constituir opção de "profissão". Para a pessoa que se prostitui e não travesti, é dada a opção de exercer outras funções no mercado de trabalho, mas para as travestis em muitos casos essa situação não é colocada. Tendo isso, a prostituição para a travesti configura-se como um trabalho de caráter explorado, como os outros trabalhos colocados na sociedade do capital. Para as travestis, trabalho e exploração se configuram como conceitos diferenciados entre si, que não compartilham da mesma matriz ideológica opressora.

ná

${ }^{2}$ Aversão ou medo de travestis, transexuais e transgêneros. 


\subsection{Justificativa.}

\subsubsection{Importância do Estudo no Contexto da Formação como Assistente Social.}

Conforme disposto no Código de Ética Profissional dos (as) Assistentes Sociais (CFESS, 1993) como princípios fundamentais estão: Empenho na eliminação de todas as formas de preconceito, incentivando o respeito à diversidade, à participação de grupos socialmente discriminados e à discussão das diferenças; Garantia do pluralismo, através do respeito às correntes profissionais democráticas existentes e suas expressões teóricas, e compromisso com o constante aprimoramento intelectual; Opção por um projeto profissional vinculado ao processo de construção de uma nova ordem societária, sem dominação - exploração de classe, etnia e gênero.

O (a) profissional assistente social deverá compreender as mudanças do mundo atual, de forma a evitar que as práticas conservadoras continuem a aprisionar corpos, mentes, desejos e expressões deles. Para, além disso, é importante estar atento (a) ao desenvolvimento da subjetividade, dando atenção a princípios como individualidade e identidade. $\mathrm{O}$ grande desafio do Serviço Social é a promessa de superar a forma de como o conceito de gênero estereotipou homens e mulheres, para pensar o humano. O exercício do Serviço Social deverá ser de enfrentamento as discriminações, por questões de inserção de classe social, gênero, etnia, religião, nacionalidade, orientação sexual, idade e condição física.

A atuação profissional do Serviço Social tem em seu projeto ético-político o compromisso com a desconstrução, criticando as totalidades universais. Permitindo assim que o transgenderismo ${ }^{3}$ relativize a lógica vigente e seus valores que fazem parte da moral pública, para não contribuir com a disciplina sexual e o estigma dos papéis de gênero. Dentro de uma

ná

3 Transgenderismo é o contraponto ao sistema de bipolaridade e dualidade de gênero (feminino e masculino) socialmente estabelecido, rechaça a construção das "genitais culturais", ou seja, renuncia a associação do gênero com as genitais, adotando novas práticas de desconstrução e redefinição dos gêneros (NIETO, 1998) 
perspectiva foucaultiana, entra em questão uma das instâncias de poder que não está focalizada só no poder do macho personificado no sistema patriarcalista ${ }^{4}$ vigente.

A escolha pelo segmento das travestis se expressa pela necessidade de evidenciar vários conceitos, relacionados à temática, que podem revelar à profissão do (a) Assistente Social, elementos que respaldem a construção de uma intervenção junto a essa categoria. Conceitos tais como: 1. Gênero e correlatos, como identidade, performance, metamorfose e suas demais expressões; 2. Homossexualidade e homossexuais; 3. Políticas Públicas especificamente para esse segmento; 4. Prostituição de travestis como fenômeno real, concreto e crescente entre outros temas. Essas concepções devem contribuir para o resgate das travestis como sujeitos de direitos, com necessidade de abordagens diferenciadas e aponta para a implementação de políticas públicas especificamente direcionadas. A invisibilização e o conservadorismo que divide os (as) homossexuais dos sujeitos "normais", nega direitos como o casamento, guarda de filhos (as), direitos previdenciários extensivos ao (a) companheiro (a) e principalmente a oferta de serviços que desenvolvam processos de transexualização onde possam ser garantidos pelo sistema público de saúde entre outros.

\subsubsection{Importância do Estudo em relação ao Conhecimento Científico.}

Essa pesquisa pretende evidenciar o universo das travestis H-M e entender por que elas são controladas e estigmatizadas como anormais/aberrações/doentes dentro de uma lógica heterosexista $^{5}$ de dominação, compreender como travestis criam seu próprio mundo. Nesse caso, o ná

${ }^{4}$ Patriarcado traz a noção de relações hierarquizadas entre seres separados por poderes desiguais, é ele que traz as ferramentas explicativas para as desigualdades. As diferenças sexuais presentes no ser macho ou fêmea são transformadas em subordinação histórica das mulheres. A questão da violência contra a mulher é um exemplo típico de como as desigualdades se manifestam (SAFFIOTI \& HELEIETH I.B, 1995)

${ }^{5}$ A assunção de uma identidade de gênero/sexual (masculino/feminino e heterossexual/homossexual) longe de se dar de maneira congênita é construída por mecanismos que compõem um "aparato regulatório" da heterossexualidade, conjunto de técnicas que estão dispostas e que reiteram a si mesmas através da "produção forçosa do sexo", de modo que a assunção da sexualidade é, desde o começo, constituída de acordo com este "aparato", esta lei reguladora de corpos e práticas. A norma regulatória age como um tipo de poder que ao marcar, diferenciar, classificar é capaz de produzir os corpos que nomeia, de modo que a materialização do sexo num corpo não é simplesmente resultado de uma plástica estético-fisiológica, mas sim da reiteração discursiva que se impõe e interpela este corpo. Esta prática 
objetivo é de compreender a partir da percepção das próprias travestis como elas se vêem na atividade da prostituição.

$\mathrm{O}$ que tem sido estudado pelo mundo científico ocidental atual relativo às travestis ainda é insuficiente, o que se observa é que a discussão ainda é recente e em decorrência disso o número de trabalhos científicos que abordem a temática é irrisório. O primeiro passo é o reconhecimento das travestis como segmento que necessita de uma abordagem teórica - prática específica que atinja categorias fundamentais na construção do conhecimento do grupo agregando conceitos essenciais para a discussão de uma nova ordem do gênero/sexo.

O transformar, o reinventar e o desconstruir são a tônica que os corpos estigmatizados das travestis estão inseridos, ainda que limitados por discursos de poder para convencioná-los como seres "anormais". Tal discurso configura-se pela definição de gênero o que dificulta ou até mesmo impede que as travestis modifiquem os papéis pré-definidos pela estrutura patriarcal.

O conceito de Aparelhos Ideológicos do Estado (ALTHUSSER, 1985) e todo seu aparato institucional, esclarecem que a ideologia se materializa nestes aparelhos, que funcionam como instrumentos conceituais. São diversos os Aparelhos Ideológicos do Estado (AIE's): religioso (sistema das diferentes igrejas), escolar (sistema de diferentes escolas públicas e particulares), familiar, jurídico, político, sindical, informação e cultural.

Esses AIE's são construtores de duas únicas identidades de gênero aceitas no padrão de normalidade sócio-reprodutiva. Isso quer dizer que ao nascer homem biológico correspondendo a compreensão de sexo, o indivíduo deverá intrinsecamente assumir a identidade de gênero masculina. A noção de que podem existir seres que transitem entre essas duas categorias ou se (re) inventem mediante isso, não é admitida como possível de haver. Cria-se, assim uma teia composta das mais variadas formas de dominação que controla e normatiza através de múltiplos processos de poder que são definidores das construções sociais.

O gênero é uma categoria social imposta sobre o corpo sexuado. (SCOTT, 1990). A desconstrução do que perpetua e reproduz o que definimos como categoria gênero tem mudado,

io

hegemônica se mantém através da repetição incansável de atuações performáticas, então, não pode continuar a existir sem uma produção ritualística pela qual é continuamente reinstalada. Estas produções são constituídas dentro de relações de poder que configuram as "verdades" que estão estabelecidas em um momento. (SAFFIOTI \& HELEIETH I.B, 1995) 
pois uma parte da sociedade que está "presa" a corpos estigmatizados, como as travestis, o que se exige um olhar para além do gênero.

Michel de Focault, não só em "Historia da Sexualidade I: A Vontade de Saber" (1976), mas em todo seu legado, diz claramente que há um discurso sobre a sexualidade e sob todos os aspectos do sexo que visa produzir verdades sobre ele. Produz-se um discurso que redime, condena e domina, sendo tudo isso, fruto da medicalização que transporta do campo do normal ao campo do patológico dentro das representações sexuais. O discurso médico, protegido pela neutralidade científica, produz crescentes verdades sobre o sexo ligadas a uma moral da assepsia e da conexão entre o "patológico" e o "pecaminoso". Essa abordagem também impede que travestis se manifestem e potencializem a desconstrução e a criação de uma nova identidade de gênero.

Transgredindo os padrões e se colocando como assunto tabu da nossa sociedade, as travestis começam a demandar novos desenvolvimentos no sentido de se compreender esta população e de redefinir conceitos que traduzam verdadeiramente quem são esses indivíduos.

A corrente teórica que norteia o presente trabalho é o marxismo, onde trabalho na sociedade do capital possui valor e se constitui como o meio para a obtenção de mercadorias para a sua existência. Nessa relação a força de trabalho se caracteriza como o próprio exercício da capacidade produtiva dos seres, onde eles estipulam o seu valor (BOTTOMORE, 1988). É à força de trabalho que os (as) que necessitam vendem em troca de ganho financeiro que configure renda. Os produtos resultantes do trabalho podem assim ser comprados e vendidos.

O capitalista investe dinheiro para a compra de mercadorias e posteriormente as vende por mais dinheiro. Isso é realizado sistematicamente quando existe mercadoria cuja utilização aumente o seu valor. A força de trabalho é precisamente essa mercadoria, ou seja, a única que com a compra e o uso o capitalista obtém trabalho e essa é a fonte de valor.

A prostituição de travestis não é fato novo além de ser cada vez mais recorrente. Pouco tem se discutindo deixando expostas várias vulnerabilidades iminentes, em um quadro de extrema marginalização do segmento. Pensar travestis como integrantes nesse processo, não é tarefa fácil, tendo em vista que muitas categorias como identidade de gênero, performance de gênero e transexualidade estão envolvidas, além de compreender o que impulsiona a participação do grupo na prostituição. O panorama exposto revela uma infinidade de categorias 
não trabalhadas e que merecem ser problematizadas para que nas ciências sociais não perdurem concepções que fiquem submetidas ao campo do obscurantismo.

É preciso ter a compreensão da importância de outras orientações identitárias, o campo de reflexão deverá estar além das diferenças sexuais. Outros elementos devem ser considerados, trata-se de reconhecer representações lingüísticas e culturais nas suas experiências em relação as outras esferas de identidade dos sujeitos. O objetivo é possibilitar a existência de seres nãohomogêneos, múltiploes e contraditórios (as), que vão além dos discursos dominantes (ROSE, 1993).

\subsubsection{Importância do Estudo em relação às Políticas Públicas.}

O contato com a bibliografia acerca das políticas públicas e programas governamentais que abordam a questão da identidade de gênero e especificamente do grupo das travestis, serve de respaldo para esse trabalho que tenta oportunizar e expor um quadro de vulnerabilidades emergentes para que sejam pensadas ações futuras que abordem as especificidades do grupo. Além de dar visibilidade e reconhecimento da relação intrínseca que acaba se estabelecendo entre travestis e a atividade da prostituição.

No que toca a construção da identidade de gênero, o segmento vivencia um panorama de profunda discriminação, exclusão e desconhecimento. Travestis se expressam como principais protagonistas desse processo marcadas pela vivência prática da desconstrução da normativa hetero-sexista, trazendo a proposta de reflexão dos opostos orientação sexual e identidade de gênero (GRANER, 2006).

A incompreensão sobre identidade de gênero (seu devido valor na sexualidade humana e possíveis expressões vivenciais a partir de seu estabelecimento) tem ocasionado violento processo de exclusão social de travestis expressos em: Evasão Escolar - Baixa Escolaridade; Despreparo Técnico e Profissional; Discriminação no Mercado De Trabalho; Violência Social e Institucional; Prostituição (GRANER, 2006). 
Nesse contexto, uma gama de vulnerabilidades pessoais é colocada, como a nãoapropriação do protagonismo numa atuação social e política; e a perpetuação da configuração do estereótipo de vulgaridade e violência no imaginário coletivo. $\mathrm{O}$ despreparo dos/das profissionais da rede pública em diversos setores e níveis, quanto à travestilidade e seus múltiplos fatores vivenciais, refletem um sistema negligente quanto a programas e ações que atendam a demandas especificas. Sendo assim, o que se acompanha é a inexistência de atenção diferenciada pelo contingente quantitativo ínfimo de travestis que se utilizam e necessitam de abordagem especifica de políticas sociais.

As primeiras políticas públicas destinadas à travestis no Brasil, ocorrem na década de 90 e em 2000, onde foram executados projetos de prevenção em DST/AIDS. O estabelecimento jurídico da Articulação Nacional de Travestis, Transexuais e Transgeneros (ANTRA) e o lançamento da campanha Travesti e Respeito, com o objetivo de contribuir para o combate ao preconceito e a inclusão social do grupo, por meio da distribuição de cartilhas, cartazes e propaganda em rádio.

A performance de gênero associado a um conjunto de determinados estereótipos, tornam as travestis mais suscetíveis a violência homofóbica em diversas instâncias.

Nesse sentido, o grau de exposição a atos violentos separa muito nitidamente diferentes categorias - gays, lésbicas e travestis- freqüentemente agrupadas sob a genérica rubrica de "homossexuais". As travestis parecem ser particularmente vulneráveis aos crimes de execução. Isso se deve tanto ao envolvimento com a atividade de prostituição, que as coloca numa posição de maior exposição pública, quanto ao modo pelo qual a homofobia as atinge. Assim, há casos em que a identidade de gênero suposta da vítima, o fato de "ser travesti", parece ser o fator determinante da execução - que assume as feições de um crime de ódio. (CARRARA e VIANA, 2006)

Por outro lado, a motivação pode estar associada a outras circunstâncias, como envolvimento com o tráfico de drogas ou em conflitos relativos a problemas quanto ao pagamento de "taxas de proteção" a cafetões ou cafetinas que controlam determinados pontos de prostituição de travestis. Revelando-se principalmente nas execuções de travestis, temos a 
evocação de uma imagem da desordem urbana, em que o duplo desvio sexual (homossexualidade e prostituição) aparece conectado à pobreza, ao tráfico e às favelas.

No tocante a essa população, é visível a ligação entre hierarquia de classe e gênero, já que as vítimas são normalmente travestis ou homossexuais pobres, envolvidos com prostituição ou moradores de favelas, que são colocados como espaço mais estigmatizante da homossexualidade.

\begin{abstract}
A indiferença policial na apuração da maior parte desses crimes parece encontrar eco nas representações negativas de travestis como homossexuais especialmente desajustados, de modo que sua morte, em geral em idade bem inferior do que a das vítimas de latrocínio, tende a ser tomada por policiais como consequiência de um modo de vida constantemente próximo da ilegalidade e que é recebida com poucas pressões, sobretudo familiares, por sua apuração e por justiça. (CARRARA e VIANNA, 2006)
\end{abstract}

Aproximadamente, $70 \%$ dos homossexuais, bissexuais e pessoas trans (travestis e transexuais) entrevistados na pesquisa Sexualidade, Cidadania e Homofobia relataram ter sido vítimas de discriminação devido à orientação sexual. Desse total, 59\% afirmaram ter sofrido uma ou mais agressões ao longo de toda a vida. A pesquisa foi realizada pela Associação da Parada do Orgulho LGBT de São Paulo. De acordo ainda com a pesquisa, foram vítimas de agressões verbais ou ameaças 55\% dos gays, lésbicas bissexuais e transexuais entrevistados. Outros $15 \%$ contam que sofreram violência física, $11 \%$ foram chantageados ou extorquidos e ainda $6 \%$ abusados sexualmente. Quase metade (48\%) dos agressores são pessoas desconhecidas, que praticaram a violência em locais públicos. Dentro de casa o ambiente a aparecer como o segundo no índice de violência; o segmento LGBT afirma ter sido atacado pelos próprios parentes. Eles ficam em segundo lugar entre os maiores agressores (12\%).

A discriminação devido à sexualidade, de acordo com a pesquisa aconteceu principalmente em ambientes divididos com amigos ou vizinhos (32\%), nas escolas ou nas faculdades (29\%) e, mais uma vez, no ambiente familiar (26\%). Entre os LGBT, o grupo trans (travestis e transexuais) foi o que mais sofreu preconceito. 
De acordo com Elaine Behring (2006), a autora afirma que o reconhecimento da existência de políticas sociais está associado à constituição da sociedade burguesa, ao modo capitalista de produzir e se reproduzir.

Ivanete Boschetti e Elaine Behring (2007) revelam que as políticas sociais devem ser entendidas a partir da compreensão de sua inserção na lógica do capital, enquanto "expressão contraditória da realidade". Considerando também uma "dimensão cultural” que está relacionada à política, levando em consideração que os sujeitos sociais são portadores de valores. Boschetti e Behring (2007) identificam na "consolidação conservadora burguesa" a marca da intolerância, sendo que esta tem raízes e sentido político. As classes dominantes nunca assumiram compromissos democráticos e redistributivos, o que se observa é um panorama complexo para a luta em defesa da cidadania, que envolvam a constituição da política social.

É neste cenário permeado por contradições e correlação de forças que se instalarão as lutas pelo combate a homofobia e por efetivação da cidadania homossexual. A matriz da violação de direitos está na forma expressa em fobia e violência da população homossexual.

Esse TCC tem o objetivo de contribuir para a formulação de políticas sociais com o enfoque nas travestis que atuam na prostituição, estando elas suscetíveis a exposição à infecção por doenças sexualmente transmissíveis (DST) e situações de agressões, violências e assassinatos em decorrência da sua identidade de gênero. O espaço a ser analisado será o Setor Comercial Sul de Brasília por se caracterizar um dos pontos de maior incidência da prostituição. 


\section{REFERENCIAL TEÓRICO}

\subsection{Categorias norteadoras: Trabalho e Exploração.}

Para Karl Marx (1818 - 1883) a riqueza das sociedades no modo de produção capitalista se configura para acumular mercadorias. A mercadoria é definida pela sua finalidade de satisfazer as necessidades humanas materiais e espirituais, o valor - de - uso do que é produzido é determinado pela sua utilidade. Mede-se a grandeza de valor de certa mercadoria pela quantidade da substância criadora de valor nela contida: o trabalho. Dessa maneira para Marx, quanto maior a produtividade o trabalho, tanto menor o tempo de trabalho requerido para produzir uma mercadoria, e quanto menor a quantidade de trabalho que nela se cristaliza, tanto menos seu valor. Assim, a grandeza do valor de uma mercadoria varia na razão direta da quantidade, e na inversa da produtividade do trabalho que nele se aplica. (GENNARI, 2009)

Em Marx as relações sociais são definidas pela relação entre as coisas. Na sociedade do capital o que interessa para quem troca produtos é saber quanto de outras mercadorias podem receber, à medida que os costumes e valores fixam essas proporções elas derivam da natureza dos produtos do trabalho.

A força de trabalho também é uma mercadoria, apesar de seu caráter especial cujo consumo significa a própria produção do valor. Segundo a lei do valor somente o trabalho humano é capaz de produzir valor. Trabalho necessário é aquele relativo ao valor da mercadoria força - de - trabalho, ou seja, o tempo que os trabalhadores gastam para produzir o valor de si mesmos. A análise do valor permite a identificação da essência da exploração capitalista e sua distinção de outros modos de exploração. $\mathrm{O}$ valor da força de trabalho é determinado, como qualquer mercadoria, pelo tempo de trabalho necessário para a produção. O tempo de trabalho necessário para a produção da força de trabalho é idêntico àquele necessário à produção daqueles meios de subsistência, o valor da força de trabalho é o valor dos meios de subsistência necessários para a manutenção de seu proprietário. (MARX, 1980)

A exploração capitalista pode ser compreendida no nível físico onde existe exploração econômica se uma parte do produto social é sistematicamente apropriada por uma classe de não produtores diretos por costume ou por lei, ou sob a ameaça ou o uso da força, ou porque a desobediência pode levar à desorganização da reprodução social. Essa compreensão é válida 
quando os produtores (enquanto classe) são obrigados a produzir mais do que eles mesmos consomem ou controlam, o resíduo sendo apropriado por seus senhores, mestres ou empregadores. Exploração ocorre em si ao nível do capital em geral, e é mediada pela existência de relações sociais mercantis. (FILHO, 2001)

A exploração é determinada em termos sociais e é mediada pela distribuição do trabalho e de seus produtos no mercado. Trabalhadores assalariados formalmente livres são sistematicamente explorados. No capitalismo, a reprodução social é guiada pela lei do valor ou pela troca de equivalentes. Essa regra de consistência opera através dos preços, que sinalizam, refletem e estabelecem a correspondência entre as necessidades sociais e o produto social. $\mathrm{O}$ valor total é limitado pelo valor do produto social, a exploração é medida pela diferença entre valor produzido e valor apropriado. Essa interpretação implica que é pago a quem trabalha o máximo do que conseguem obter. Os aspectos da exploração derivam do monopólio capitalista dos meios de produção, da transformação das mercadorias na forma geral do produto, e do controle capitalista do processo de trabalho. (FILHO, 2001)

Correspondente a essa compreensão, quem trabalha vende no mercado sua capacidade de trabalho, ou força de trabalho, e são pagos pelo valor dessa força de trabalho. Quem trabalha está no capitalismo numa relação de exploração porque produzem mais valor do que controlam e recebem. Esse valor recebido é trocando por itens que atendam as necessidades de quem trabalha que são demandas e padrões de consumo, como eles são determinados, pode variar muito entre distintos segmentos da classe.

O valor da força de trabalho não pode ser conceituado independentemente das tendências contraditórias associadas com a acumulação de capital, para as quais é necessária uma análise complexa das estruturas de consumo, emprego e distribuição de renda. Essa análise determina a parcela do trabalho apropriada pelos trabalhadores através de uma série de mediações, que incluem o que é produzido e como, as necessidades e hábitos, e seu reflexo sobre as estruturas de produção. Cada necessidade se torna um elo na cadeia de quem trabalha. (MARX, 1972)

Quem trabalha deve se relacionar com sua força de trabalho como sua propriedade e, portanto, sua própria mercadoria, e isso ele só pode à medida que ele a coloca à disposição do comprador apenas provisoriamente, por um prazo de tempo determinado, deixando-a ao consumo, portanto, sem renunciar à sua propriedade sobre ela. (MARX, 1983, grifos meus). 
O capital continua contemplando o elemento que o movimenta que é trabalho vivo, uma vez que somente a presença desse gera o equilíbrio do sistema e continua a manter a concentração e valorização do capital. Ao passo em que são desenvolvidas as forças produtivas, o sistema do capital remunera decrescentemente o trabalho, proporcionalmente na relação em que seu valor de uso decresce como proporção do valor. O que se acompanha é um profundo mecanismo de desvalorização da força de trabalho no sentido de que nas formações sociais capitalistas, as transformações das forças produtivas implicam necessariamente, na destruição do valor de uso da força de trabalho. (RANIERI, 2006)

É porque o mercado se apropria que o conjunto das atividades financeiras determina o emprego e as formas de dominação exercidas sobre o trabalho. O capital é uma relação social de produção, onde o trabalho entra como fator central.

\subsection{História da Homossexualidade.}

A palavra "homossexualidade" apareceu pela primeira vez na língua inglesa em 1890 , usada por Charles Gilert Chaddock, tradutor de Psychopathia Sexualis, de R. Von Krafft Ebing. (Spencer, 1996). As pessoas buscaram denominar o ato de se sentir desejo, atração física e/ou emocional por pessoas do mesmo sexo, que no século XIX era conhecido como "inversão", termo também usado para definir todos os desvios a partir do padrão da época. A busca por palavras que denominem novas experiências e sensações é sinal de mudança social, o uso de novas palavras provoca questionamentos. (SPENCER, 1996)

Ainda de acordo com Spencer, os dados antropológicos têm tendido a tratar o amor homossexual como um fenômeno, escondendo referências a ela em rápidas passagens ou pés de páginas. Um detalhado estudo sobre a homossexualidade expressa em Nova Guiné (Papua) e nas ilhas da Melanésia, como as Fiji e as Salomão, no Oceano Pacífico, expressam que as evidências fornecidas pelos modelos lingüísticos e de imigração sugerem que os povos que primeiro colonizaram a Melanésia, cerca de 10.000 anos atrás, exerciam algumas formas de 
homossexualidade ritual. Esses povos praticavam rituais de iniciação entre velhos e jovens e até mesmo de travestismo.

Dentre esses povos se destacam os Marind e Kiman. Nelas, o menino passado o período da infância, era separado da mãe e tirado da casa das mulheres, para dormir com o pai na casa dos homens. Aos primeiros sinais de puberdade, o tio materno era designado a penetrar o menino analmente fornecendo-lhe o esperma que o faria forte. Os meninos que vivenciavam esse ritual, assim ficavam durante três anos.

\begin{abstract}
A tribo Marind tinha o ritual Sosom, no qual não se permitiam a presença de mulheres. Sosom era um gigante castrado que usava um colar de cabeças humanas em redor do pescoço. Um grande falo vermelho ficava numa clareira da floresta, e os meninos iniciados eram levados até ele. Os homens mais velhos dançavam, e então se seguia uma orgia masculina, na qual pela primeira vez qualquer homem podia penetrar qualquer um dos meninos iniciados. O homem Marind não interrompia suas praticas homossexuais quando se casava. No processo de produzir uma família, ele podia ser convocado para ser o iniciador do seu sobrinho, durante três ou quatro anos. (SPENCER, 1996, p.54)
\end{abstract}

Cada povo tinha as suas variações de rituais, mas havia alguns que eram comuns a muitas. Um deles considerava penetrar um menino para plantar a semente do seu próprio esperma; que ele não cresceria para ser homem, caçador forte e poderoso sem esses anos em que a pratica de sexo entre pessoas do mesmo sexo era diária.

Também é possível identificar relatos do povo que recebe o nome de Sambia que vivia no interior da selva de Nova Guiné (Papua) e somava cerca de 2.300 pessoas, acreditava que os meninos na puberdade tinham de ser alimentados com sêmen, de modo que, desde os sete anos de idade eram separados das mães e viviam na casa dos homens, onde deveriam evitar inclusive o olhar das mulheres durante os anos de ser crescimento. Nesse período, eles vivenciavam rituais de iniciação sexual, onde aprendiam a praticar felação com os homens e os meninos mais velhos. 
Esses meninos trocavam de papéis e ensinavam a prática aos novos iniciados, mais jovens que eles. Quando este mostrava sinais de maturidade sexual, fazia-se uma cerimônia, após a qual ele se juntava aos homens e se tornava um caçador. Homossexualidade feminina nãoinstitucionalizada nesse corte temporal era muito rara e pouco se sabe a respeito dela.

$\mathrm{Na}$ Mesopotâmia, mais precisamente na Babilônia, se um homem possuísse por trás um igual, adquiria proeminência entre os irmãos e colegas desse. Se mantivesse relações com um cortesão durante um ano inteiro, estava salvo de todas as suas preocupações. Mas se um homem tivesse relações com o seu escravo, estaria em dificuldades. Se penetrasse alguém de status social superior ou do mesmo nível podia trazer boa sorte.

Em torno do Rio Amarelo e seus dois afluentes, o Wei e o Fen, a China da dinastia Zhou (1122-256 ${ }^{\text {.CC. }}$ caracterizava-se uma confederação de estados que reconheciam nominalmente o rei Zhou e estavam unidos por casamentos clãs e dinásticos. Os relatos da época transmitem uma expressão vivida de uma homossexualidade aberta na vida da corte, mas não existia uma palavra precisa para homossexualidade que expressasse esse tipo de amor.

Em Creta na Grécia, existe o registro de que era praticada a ascensão dos meninos naquela ilha, era considerada uma convenção social da época. De acordo com os costumes em Creta, o amante presenteava o menino e o levava para as florestas e/ou montanhas, onde viviam cerca de dois meses. Nesse período, o amante ensinava o menino a caçar, a viver em ambiente inóspito e a se tornar um homem honrado. Também fazia amor com o menino o penetrando analmente. Depois de dois meses, o menino era enviado para casa com presentes. O que se sabe e que os rituais de iniciação dos meninos eram parte da estrutura social da época, mas a homossexualidade física nas sagas deve ser em sua maioria inferida. No século VI a.C. houve um extraordinário florescimento da poesia lírica homossexual.

Em Atenas, a norma social era a bissexualidade, mas esse conceito era limitado por muitas qualificações. Não era socialmente bem aceito um homem ser amante apenas de rapazes, uma bissexualidade equilibrada, na qual um cidadão era casado tinha um relacionamento amoroso com um rapazinho e era também visto com cortesãs ou tinha uma amante, era comportamento normal. (SPENCER, 1996) 
Em Esparta, todas as melhores mulheres que tinham mais relevância costumavam amar garotas e se acontecesse de duas mulheres se apaixonarem pela mesma garota, elas tentavam entrar em acordo e aprimorar a bem-amada. Um retrato feito por Luciano de Samosata, no quinto de seus Diálogos de cortesãs. Clonria ouviu dizer que Lena e amante de uma rica dama de Lesbos, Megilla. Lena admite que isso é verdade e conta o quanto Megilla e masculina: raspa a cabeça. Mas usa peruca durante o dia , para disfarçar. Não utiliza um "utensílio de homem”, por ter seu próprio jeito de fazer amor, que e muito mais prazeroso. Megilla lhe diz que embora nascida mulher, todos os seus desejos são de um homem.

Roma seguiu a tradição das antigas civilizações de celebrar a bissexualidade masculina. No século II a.C. ocorreu aparentemente uma mudança nos costumes sexuais. A idéia do macho dominante romano foi sendo influenciada pela Grécia. O amor por meninos estava na moda. Se um romano quisesse assegurar respeito e fidelidade, então escolhia uma esposa. Mas se desejava paixão sexual, angustia e ardor romântico, escolhia um jovem. Se alguém se desse bem com meninos e meninas, isso não era relevante mas sim o que fazia sexualmente com eles e/ou elas. $\mathrm{O}$ homem romano jamais deveria desempenhar o papel passivo na relação e poderia obrigar os seus escravos a fazer felação nele, mas um romano jamais poderia fazer felações em seus escravos. (SPENCER, 1996)

No inicio aceitava-se sem discussão que os meninos e belos jovens eram desejáveis sexualmente, o amor pelos meninos era muito popular, ainda que a Lex Sacatinia (promulgada em torno de 226 a.C. e destinada regular o comportamento sexual), o relacionamento sexual com um menino fosse punido com multa. Isso, no entanto, mudou gradualmente ao final do Império Romano ate essa pratica ser finalmente proibida e repudiada. Em Roma a homossexualidade feminina era altamente rechaçada. A lesbianidade feminina afrontava a masculinidade romana, porque roubava dela o direito de dar prazer. Era visto como uma tentativa, de uma mulher usurpar o papel de um homem. Nero casou-se com seu escravo castrado, Esporo, e o beijava freqüentemente em publico. Cesar tivera um caso com Nicomedes ${ }^{6}$, ele era chamado de "Rainha"

ná

${ }^{6}$ Nicomedes, IV, rei da Bitínia. Nicomedes é uma personagem histórica que viveu no século I a.C., em um reino do Oriente, hoje, região noroeste da Turquia, na parte asiática. (SPENCER, 1996) 
por Otavio ${ }^{7}$, nas assembléias publicas, por ter sido visto num banquete dado por Nicomedes, com outros exoleti (homossexuais passivos). Cesar era ridicularizado em publico, mas costumava ser chamado de omnium virorum mulier, omnium mulierum virum (mulher de todos os homens e homem de todas as mulheres). O travestismo era repudiado em Roma, sendo negadas as pessoas que tivessem trejeitos afeminados. (SPENCER, 1996)

Na Índia não há duvidas de que o comportamento homossexual existia desde os tempos mais antigos. O grande panteão de deusas e deuses da religião hindu inclui divindades hermafroditas, travestidas e ainda outras que podem mudar de sexo. Isso deriva da idéia de que o Ser Supremo possui ao mesmo tempo características femininas e masculinas, o tantrismo ensina que todo homem tem em si elementos femininos e toda mulher, elementos masculinos. Ate 1948, quando a Índia se tornou independente, alguns templos hindus havia grupos de travestis masculinos ou transexuais devotos da Deusa Mãe ${ }^{8}$, que cantavam, dançavam e pediam esmolas nas cidades do Norte da Índia. Eles também praticavam a prostituição homossexual. A homossexualidade nunca foi um problema na cultura indiana, embora na Índia alguns considerem que o ato exige purificação ritual.

No candomblé e religiões de matrizes africanas, os orixás assumem formas femininas e masculinas, além de exercerem a prática da homossexualidade com naturalidade. Há Orixás que têm vida sexual bastante irregular de acordo com os padrões oficiais de nossa cultura sexual (Iemanjá casou-se com o irmão e foi violentada por seu próprio filho de quem teve outro filho); há Orixás que são transexuais, isto é, mudam de sexo, como Logun-Edé e Oxumaré, que uma metade do ano são homens, a outra metade, mulher. (MOTT, 2008, grifos meus)

ná

${ }^{7}$ Otávio Augusto, (63-14 d.C.). Primeiro imperador romano, filho de Caio Otávio e Átia e sobrinho-neto de Júlio César, que o adotou e o fez seu herdeiro. Caius Octavius que se tornou, por adoção, Caio Júlio César Otaviano e posteriormente, César Augusto, o Augusto, foi o idealizador da pax romana e do império, um extraordinário político e administrador. Sem revogar as leis e instituições republicanas, concentrou todo o poder em suas mãos, inaugurando uma época de esplendor e prosperidade no mundo antigo.

${ }^{8}$ Quando os povos antigos identificaram a mulher com a Terra e associaram a existência da Terra a poderes divinos, consideraram que o poder que conspirou para que o Universo fosse criado era feminino. Como só as mulheres têm o poder de dar a vida a outros seres, nossos ancestrais começaram a acreditar que tudo tinha sido gerado por uma Deusa. (SPENCER, 1996) 
Observa-se que na construção histórica e mítica do candomblé Logun-Edé e Oxumaré se aproximam em suas expressões comportamentos que podem ser aproximados a transexuais, incorporando ao longo do ano, os dois sexos. O próprio Oxalá também participa desta dualidade, pois segundo alguns do candomblé, reúne em si o lado masculino e feminino - aliás, como muitos outros deuses antigos. Pelo Brasil muitos e travestis e gays, sobretudo de classes mais humildes, incorporaram palavras de inspiração yoruba ${ }^{9}$ em seu linguajar diário. Alguns exemplos: mona=mulher; adé=gay; aló=lésbica; edi=pênis; ocan=bunda; ocó=homem; uó=coisa ruim. (MOTT, 2008, grifos meus)

\subsection{Relatos sobre a Homossexualidade no Brasil.}

Relacionado à sexualidade dos índios Tupinambá, as primeiras condutas relatadas foram relacionadas ao comportamento totalmente livre de pudores.

“... é a relação absolutamente neutra que tais silvícolas mantinham com a nudez, além de primarem por desbragada luxúria, falando constantemente entre si de suas "sujidades", incansáveis em procurar variegados gozos eróticos, conhecendo diversos afrodisíacos e magias sexuais, que os cristãos interpretaram como coisas do Diabo. Não só os Tupinambá, como diversas outras tribos nas três Américas, abrigavam em suas aldeias grande número de "invertidos sexuais" de ambos os sexos, chamando aos homossexuais masculinos de "tibira" e às lésbicas de "çacoaimbeguira". (MOTT, 2001)

ná

${ }^{9} \mathrm{O}$ ioruba, ioruba ou yoruba é um idioma da família lingüística nigero-congolesa e é falado ao sul do Saara na África. No c andomblé é a língua utilizada para denominar orixás e rituais. (ALMEIDA , 2006) 
Dentre as minorias sociais formadoras do povo brasileiro, os homossexuais representam o grupo social cuja história de gays, lésbicas e travestis constituem um dos grupos sociais cuja memória é rica de detalhes.

No Brasil antigo, a homossexualidade, então chamada de "sodomia", foi considerada dentre todos os crimes, como o mais hediondo, equiparado na sua punição, aos delitos de lesa majestade e à traição nacional. Por sua condição de crime gravíssimo, perseguido por três instâncias jurídicas, foi o delito que deixou maior quantidade de registros e oferece maiores recursos para o resgate da memória. (MOTT, 2001)

Dentre todos os pecados, bem parece ser o mais torpe, sujo e desonesto o pecado da Sodomia, e não é achado um outro tão aborrecido ante a Deus e o mundo, pois por ele não somente é feita ofensa ao Criador da natureza, que é Deus, mais ainda se pode dizer, que toda a natureza criada, assim celestial como humana, é grandemente ofendida.. (MOTT, 1988, p.22)

A sodomia tornou-se crime punível por três diferentes tribunais: a justiça del Rei, do Bispo e da Santa Inquisição. Tal condenação devia-se à antiga superstição adotada pela Igreja Católica, onde a cópula anal atiçava a ira divina, colocando em grave risco o equilíbrio do mundo criado por Deus. (BOSWELL, 1994). De acordo com o cristianismo, somente o ato de pronunciar a palavra "sodomia", gerava uma série de tragédias.

\footnotetext{
"Somente falando os homens neste pecado, sem outro ato algum, tão grande é o seu aborrecimento, que o ar não o pode sofrer, mas naturalmente fica corrompido e perde sua natural virtude. Por este pecado lançou Deus o dilúvio sobre a terra e por este pecado soverteu as cidades de Sodoma e Gomorra; por este pecado foi destruída a Ordem dos Templários por toda Cristandade em um dia. Portanto mandamos que todo homem que tal pecado fizer, por qualquer guisa que ser possa, seja queimado e feito pelo fogo em pó, por tal que já nunca de seu e corpo e sepultura possa ser ouvida memória" (MOTT, 2007)
} 
Homens que eram definidos como sodomitas, representavam "os traidores da nação", confrontavam a ideologia machista, patriarcal e falocrática ${ }^{10}$, pois fragilizavam a imagem da invencibilidade do macho e de seus comportamentos sexuais sejam com mulheres de todas as raças e estamentos, sejam outros machos que por ventura se "deixassem dominar". (MOTT, 1994)

Com a finalidade de evitar o risco de ameaça a ordem estamental que os aparelhos ideológicos do estado colonialista - o Rei, a Igreja e as elites fundiárias - se uniram para perseguir os que amassem pessoas do mesmo sexo. Muitos homossexuais foram aprisionados em cárceres, tiveram seus bens sequestrados, açoitaram-nos publicamente, divulgando nos Autos de Fé suas sentenças com humilhantes detalhes íntimos. Alguns eram mandados para terras longes onde eram abandonados os criminosos, outros eram condenados à fogueira. (MOTT, 1994).

Esse tipo de conduta continuou a perdurar e é retomado pela legislação luso-brasileira, tanto religiosa como civil, ao defender que "somente falando os homens no pecado de sodomia, sem outro ato algum, tão grande é o seu aborrecimento, que o ar não o pode sofrer, mas naturalmente fica corrompido e perde sua natural virtude" - incluindo Santo Tomás de Aquino a homossexualidade no rol dos pecados contra a natureza. (MOTT, 1994)

O sistema punitivo de Portugal costuma condenar criminosos por delitos de estupro, roubo e crimes políticos a exílio em terras diferentes às da nação, ou até mesmo em lugares que na época representavam os presídios. No caso dos sodomitas, a legislação determinava exatamente o oposto: que tais réus fossem queimados, e suas cinzas varridas da superfície da terra.

Além de se extinguir a lembrança física dos restos mortais do sodomita, os próprios familiares jogavam uma pá de cal sobre a memória do condenado por homossexualidade. Tal condenação tornava a sua família inábil por três gerações para ocupar cargos públicos, eclesiásticos e militares.

$\mathrm{Na}$ contemporaneidade, famílias continuam a manter práticas agressivas contra seus membros homossexuais: recentemente, em Salvador, um pai ao saber que seu filho adolescente era homossexual, entregou-lhe um revólver, ordenando: "se mate! pois na nossa família nunca ná 
teve viado!" A tradicional família do mais exuberante carnavalesco da Bahia, Evandro Castro Maia, nos anos 50, inconformada com sua homossexualidade, expulsou-o para o Rio de Janeiro, pressionando para que retornasse logo para seu exílio nas raras vezes que voltava a sua terra natal. Muitos são os casos conservados no Arquivo do Grupo Gay da Bahia onde se registra que familiares pressionam policiais e jornalistas para que omitam a homossexualidade de seus parentes quando vítimas de crimes homofóbicos. É prática corrente na generalidade das famílias brasileiras a destruição de cartas, diários, livros, fotos e materiais pessoais logo após o falecimento de parentes gays, lésbicas e travestis, destruindo-se assim a memória daquela "ovelha negra" da família. (MOTT, 2007)

\subsection{Gênero, identidade de gênero, subversão do gênero}

Para compreendermos a categoria gênero é preciso remeter às relações estabelecidas partindo da percepção social das diferenças biológicas entre os sexos, refletir sobre os esquemas classificatórios de feminino/masculino que criam marcadas oposições e diferenciações entre essas categorias. Essa diferenciação é marcada pela hierarquia onde o masculino é reconhecido como símbolo da força e autoridade. A partir disso historicamente arbitrário foi construída a percepção do feminino que se caracterizou em oposição ao masculino, o sexo frágil, fraco e de práticas marcadas pela submissão (SCOTT, 1990).

Como nossa sociedade estabeleceu as categorias de gênero a partir do padrão biológico de distinção anatômica, é recorrente colocar sexo, gênero e sexualidade como se tivessem um conceito comum. Por exemplo, no momento em que nasce uma criança que pertence biologicamente ao sexo feminino, associa-se a ela o gênero feminino e a sexualidade heterossexual, considerando que a sociedade a define como a "normal". Historicamente se atesta que as identidades de gênero têm sido construídas e reforçadas dessa forma. (BUTLER, 2003)

Dessa maneira, casos de pessoas que mudam o sexo ainda causam muito impacto. O que não é visto de maneira crítica pela sociedade é que mais difícil para os indivíduos é o sentimento 
de não possuir identidade nenhuma. Os parâmetros ideais de oposição dos sexos, ainda são tão fortes que não conseguimos cogitar a hipótese da existência de um terceiro sexo, de um ser intersexuado, de um "meio-termo" ou de um andrógino. (DOMINGUES, 2008)

$\mathrm{Na}$ Antiguidade muitas sociedades aceitavam e respeitavam a existência de três gêneros: macho, fêmea e andrógino. O andrógino era classificado como uma fusão de opostos, uma conjunção dos sexos. Muitos eram vistos como seres perfeitos e adorados como divindades. (DUBY, G. PERROT, M, 1990)

No período da Idade Média, os hermafroditas eram criados com um determinado gênero e quando atingiam a puberdade/fase adulta, lhes era determinado o direito de optar por outra identidade, conforme se julgasse necessário. No entanto, a partir do momento em que as pessoas estabeleciam sua preferência, não poderiam mais trocá-la. (DOMINGUES, 2008) Caso isso acontecesse, estariam sujeitos a sofrer discriminações e condenações. Essa liberdade de escolha, todavia, chegaria ao fim com a constituição de novas concepções a respeito do indivíduo, da sexualidade e com a formação dos Estados Modernos. (FOUCAULT, 1983)

Os papéis que homens e mulheres assumem em sociedade, são decorrentes da divisão entre os sexos que afeta diretamente na construção das identidades. Essa percepção foi notadamente incorporada pelo Estado, instituições e seus agentes onde todos funcionam como esquemas da percepção, do pensamento e da ação (BOURDIEU, 1999). Compreender de que maneira essas oposições se expressam contribui também para perceber a relação entre sexualidade e poder. A sexualidade é construída a partir das condutas sociais e que fundamentam a construção das identidades. (BOZON e GIAMI, 1999)

A sexualidade passa pelos esquemas de oposição e hierarquização entre masculino e feminino, onde as práticas sexuais bem como o que as envolve (palavras, imagens, condutas), expressam sutil ou escancaradamente a todo o momento a relação de dominação construída entre os dois sexos. Dessa maneira, a dominação masculina se expressa na qualidade de que o homem é o sujeito e a mulher o objeto, essa disposição traz em sua raiz a heterossexualidade como norma e define as práticas sexuais dos dois sexos cada um segundo a sua "natureza" (BOZON, 1999).

Tendo esse contexto, a homossexualidade subverte essa norma, mas ainda remetendo a homossexualidade masculina a uma posição inferior, também de dominada (ANJOS, 2000). A 
percepção da homossexualidade como enfermidade e não mais como pecado, foi construída historicamente pela medicina e psiquiatria Esse fundamento foi baseado na percepção das naturezas de mulheres e homens e na identificação do homossexual com a natureza feminina. Para a homossexualidade feminina, a explicação era pautada na possibilidade de subversão de uma posição de subordinação e da negação do papel atribuído à mulher, inclusive a sujeição sexual ao homem. (ANJOS, 2000)

Transgêneros assumem em suas identidades corporais, psíquicas e sociais a possibilidade de transitar entre os gêneros. Para alguns/algumas, transgêneros são as pessoas que ultrapassam barreiras não se fixando a um conceito determinado ou as que estão em processo de identificação com algum gênero buscando estabelecer o processo de construção de suas identidades. Transgênero não é uma orientação sexual, é uma definição de gênero e não de sexualidade.

Trabalhos publicados nas décadas de 20 e 30 do século XX demonstraram que nesse período o tema chamou muita atenção de médicos e estudiosos. Esse período coincide com a implantação de políticas higienistas no Brasil. Ao final do século XIX e início do século XX, com a reorganização política do modelo republicano, o cenário da vida cotidiana foi construindo novos discursos, modelos, novas práticas e colorações. No cerne dessas discussões surgiu a ideologia higienista que tinha por finalidade normatizar as condutas sociais através das práticas médico/sanitaristas que pregava o aperfeiçoamento da raça humana.

Para compreender o corpo, o que era observado era o aspecto biológico/natural com fundo extremamente moral. Os corpos e suas complexas demonstrações passaram a refletir funções sociais e morais. (DOMINGUES, 2008)

A distinção biológica existente entre homens e mulheres propiciou a formação efetiva dos papéis femininos e masculinos. O corpo da mulher era pensado a partir da função social de mãe e por esse motivo ela deveria se voltar para a esfera do lar. O corpo do homem se estabelecia na relação de progenitor e dominador do espaço público.

$\mathrm{O}$ que se estabeleceu entre feminino e masculino, foi norteado exclusivamente pelos aspectos que os diferenciavam. Os corpos então passaram a ser vistos dentro de escalas hierárquicas de poder. Por meio de suas diferenças biológicas era possível classificar os papéis sociais e políticos dos homens e das mulheres. A dimensão de caracteres biológicos foi utilizada 
como respaldo para distinguis os papéis sociais femininos e masculinos, mas essas relações de poder não se deram pela natureza e sim pela interpretação das sociedades. (LUZ, 1982)

As construções culturais em torno do feminino e do masculino legitimaram a identidade, o espaço físico, o papel social e político de cada sexo. Assim sendo, instituíram-se modelos nos quais o sexo feminino foi caracterizado como frágil, emotivo e maternal enquanto o sexo masculino foi constituído culturalmente como forte, racional e dominante.

Apesar dos modelos ideológicos justificarem as distinções dos papéis femininos e masculinos e estabelecerem o domínio do espaço público para os homens, as diferentes realidades sociais, culturais e econômicas podiam facilitar para que alguns indivíduos transitassem nas relações de poder exercidas entre o público e o privado. Ao não assumir seu papel social ou suas identidades estabelecidas biologicamente, muitas pessoas exercem outras relações de gênero e de poder. Não seguem os padrões estabelecidos e embora suas atitudes pudessem estar subordinadas a determinadas sujeições, traçam seus próprios modelos de vida, de acordo com suas vontades ou necessidades fugindo dos moldes normatizadores. (DOMIGUES, 2008)

Nessa relação os/as transgêneros estão no movimento de (re) pensar maneiras como seus gêneros e identidades de gênero se circunscrevem para a definição de seus papéis sociais, seus desejos e autonomia sobre seu próprio corpo. Perceber que o sexo biológico não corresponde à expressão de gênero coloca travestis em um espaço onde é preciso construir várias ferramentas de ressignificação.

\subsubsection{Travestismo e Travestis.}

A distinção sexo/gênero e a própria categoria sexual parecem pressupor uma generalização do "corpo", que preexiste a aquisição de seu significado sexuado. A formulação das identidades se dá por meio de processo de reconstrução constante, a idéia de identidade única e definida está decaindo. No que se refere à intervenção corporal e aos efeitos dessa intervenção na redefinição de gênero. Esta ação de repensar masculinidade e feminilidade enfatiza uma interpretação de gênero como cultural e processual. 
A noção de incorporação é de grande valia para pensar esses sujeitos. Nas duas línguas o termo é ambíguo, mas deve ser entendido como a aprendizagem e assimilação feita pelo corpo e só nele observável. (ALMEIDA, 1996: 20). Travestis ao construir sua identidade e gênero estão permanentemente em um processo de incorporação para se assimilarem cada vez mais ao gênero com que se identifica.

A incorporação está vinculada à linguagem, à vivência, à experiência, entre outros aspectos. O corpo se coloca como o principal meio de expressão, por meio dele o segmento assume a identidade performática e comunica sua própria subjetividade. As travestis por estarem atentas ao próprio corpo, o percebem mais facilmente como sendo o melhor meio de ação e identificação. A reconstrução dele indica reformulação de seus gêneros e identidades.

A identidade transparece ao se demonstrarem socialmente como mulher em tempo integral. Essa construção da identidade ultrapassa utilizar roupas que compõem o universo feminino, trata-se de vivenciar a subjetividade que compõe socialmente o que se vê como mulher. (FERREIRA, 2003)

Tendo como cenário a sociedade patriarcal onde os valores e papéis sexuais são extremamente definidos entre feminino e masculino, o corpo das travestis que ultrapassa essa lógica, demonstra-se como alvo de preconceito acarretando sérias implicações no exercer da cidadania e da compreensão e participação política desse segmento. (FERREIRA, 2003).

Estando de posse de corpos ditos marginalizados, assumindo identidades que afrontam o caráter bilateral masculino e feminino, exercendo práticas sexuais que geralmente passam por processos de compreensão profunda dos seus desejos, é nesse espaço em que as travestis começam a se perceber em outras esferas entre uma das mais significativas, a do trabalho.

Sendo assim, a participação do mercado de trabalho das travestis é quase sempre de maneira precária, mais expressiva nos segmentos de estética, gastronomia e entretenimento. Para as provenientes de famílias de baixa renda ou até mesmo as que saem de casa devido à violência, a prostituição aparece como um recorrente meio para extração de sustento financeiro. (FERREIRA, 2009)

A rua se caracteriza como importante espaço de convivência e comunicação com outras travestis. (GOFFMAN, 2005), afirma que o indivíduo quando está na presença de outros com os 
quais se identifica expressa o ímpeto de saber informações a seu respeito. Dessa maneira, indivíduos que se vêem em algum grupo que se reúnem por características comuns, passam a trocar informações entre si.

O corpo para as travestis se expressa como veículo principal de reafirmação de sua identidade de gênero, corpo esse que passa por modificações que ultrapassam a sua condição biológica e tenta transmitir a diversidade. (FERREIRA, 2009) A informação social se dá por muitas vias e a maneira como o seu corpo se expressa é uma ferramenta para falar sobre o que está em seu íntimo. (GOFFMAN, 2005)

Um dos meios o qual será foco do presente trabalho é da prostituição como meio de garantir fonte de renda. A prostituição se expressa como agravante ao quadro de vulnerabilidades desse segmento. Quando recorrem a esse meio para exercer alguma atividade para geração de renda, as travestis se comunicam entre si, e conseqüentemente com clientes, moradores do território onde é exercida a prostituição, policiais e possíveis agressores. Cada segmento que participa direta ou indiretamente da vivência social da travesti as enxerga de uma maneira.

Quando elas (travestis), passam a considerar o sexo como serviço negociado que prestam a quem procura, passam a investir em seu próprio corpo que se demonstra como o meio de fonte de renda procurando torná-lo mais atraente tendo em vista o padrão de beleza feminino vigente. Quanto mais femininas se demonstrarem, maiores são as possibilidades de negociação do corpo. (FERREIRA, 2009) As ferramentas empregadas quando se trata do corpo bem como o estilo de se vestir e se apresentar socialmente, atribui valores significativos as travestis que vivem da prostituição. Trata-se do corpo como instrumento de estímulo da libido, fantasia e desejo.

Estar na rua se prostituindo, também as expõe a inúmeras situações de violência. $O$ imaginário construído pela sociedade das travestis é de que são pessoas extremamente perigosas e marginalizadas. Em muitas ocasiões são obrigadas a recorrerem à força física para se defenderem e impor sua presença. Os relatos do que se tem registro é dos anos 1950 e 1960, faixa temporal de expressivas agressões, onde eram agredidas e presas por atentado ao pudor, situação que não mudou muito nos dias de hoje. (SILVA, 2007). No processo de passagem do gueto para as ruas, precisaram aprender a enfrentar aqueles que ofereciam perigo, não sendo raro 
utilizarem lâminas cortantes para intimidar os agressores. As tensões geralmente são causadas quando a especulação sobre o valor do programa é desrespeitada por qualquer uma das partes.

A figura que o imaginário construiu das travestis é de marginais, criminosas, vergonhosas. Imagem essa construída principalmente também pela ligação com a prática da prostituição. Tendo como base o corpo modificado das travestis como o elemento nítido da sua compreensão de gênero, esse também pode ser identificado como o alvo do estigma. A violência praticada pelos ditos heterossexuais ou pelos que não compreendem sua própria sexualidade, pode ser entendida como uma ferramenta vil de reafirmação do que foi definido como normal (heterossexualidade).

O fato é que o preconceito continua a configurar uma forte barreira ao respeito, o que se pode perceber macadamente na abertura de outras oportunidades de trabalho para esse segmento. A compreensão de cidadania é muito rasa, sendo assim poucas se compreendem como sujeito de direitos (FERREIRA, 2009). As travestis em seu entendimento de gênero são interpretadas de maneira sociodesvalorizada ou no caso da prostituição, definidas como mero objeto sexual. Apesar do contexto delicado com que lidam as travestis ainda resistem com as suas interpretações individuais do seu gênero. 


\title{
2.5. Breve histórico da Prostituição.
}

Observa-se que a prostituição tem sua matriz na consolidação do mercantilismo:

$\grave{A}$ tradição e aos costumes não repugnava - nuca repugnou - a poligenia $^{11} e$ poliandria $^{12}$, isto é, asrelações sexuais de um homem com muitas mulheres e destas com muitos homens. O mercantilismo aproveitou-se dessa disposição natural, para fins comerciais, rodeando a prostituição de leis, de privilégios, de repressões de tabus, que visavam e visam a proteger o negócio. (BRASIL, 1933, p.29)

$\mathrm{Na}$ Grécia antiga onde cada cidade era uma autarquia, na época de Cekrops, o fundador de Atenas (1.600 a.C.) reinava a comunidade das mulheres. Com o desenvolver da civilização, a propriedade individual aviltou-se. O mercantilismo desponta trazendo consigo a acumulação de riquezas e o pauperismo. A prostituição surge nesse contexto como conseqüência imediata (BRASIL, 1933)

ná

\begin{abstract}
Na Grécia, as prostitutas vulgares eram escravas e tinham o nome de porné; a casa onde exerciam o seu comércio era o porneion; e os industriais que exploravam o negócio eram os pornoboskoi. Essas mulheres pagavam um tributo pornokontelas $e$ dependiam da autoridade dos magistrados, que vigiavam a sua maneira de proceder. Viviam em Atenas num bairro reservado que tinha o nome de Cerâmico. Aí fundou Sólon um porneion para "satisfazer as necessidades do povo", sendo por isso muito louvado por seus aduladores. (BRASIL, 1933, p.35)
\end{abstract}

${ }^{11}$ Po.li.ge.ni.a: sf $\left(\right.$ poli $\left.^{1}+g e n o+i a^{1}\right)$ Antrop Teoria segundo a qual a raça humana teve origem em diversos pares independentes; multiplicidade das raças. Dicionário, 2007.

${ }^{12}$ Po.li.an.dri.a: $s f\left(\right.$ poli $\left.{ }^{1}+a n d r o+i a^{1}\right) 1$ Estado ou qualidade de poliandra. 2 Sociol Forma de matrimônio de uma mulher com vários homens, geralmente em organizações matriarcais, como se observa em algumas tribos da Polinésia etc. 3 Bot Classe da classificação de Lineu, que abrange plantas com mais de vinte estames hipóginos livres. Dicionário Michaelis, 2007. 
Existia uma classe de prostitutas consideradas superiores que eram as que exerciam funções de dançarinas, cantoras e que tocavam instrumentos musicais. A classe das hetairas, era constituída por mulheres livres, cultas e famosas, que recebiam em suas casas os políticos, os generais, os filósofos e os poetas, raras vezes, mantendo relações sexuais, simultâneas, com mais de um. Eram lícitas e regulares as relações íntimas com elas.

$\mathrm{Na}$ época auge da civilização grega as leis e os costumes permitiam aos cidadãos possuir três mulheres: a hetaira, especialmente para os prazeres do espírito; a palaca, para a direção dos serviços domésticos; e a esposa, para a procriação dos filhos legítimos.

À poligamia dos homens correspondia a poliandria das hetairas, ou melhor, uma "monogamia periódica sucessiva". Havia duas classes de hetairas em Atenas e Corinto. A primeira compunha-se de mulheres letradas; e a segunda compreendia as mulheres que, pela sua beleza, sua graça ou o seu espírito, se tornavam as favoritas dos grandes, dos príncipes e dos reis. (BRASIL, 1932, p.54)

No patriarcado moderno existe uma variedade de meios pelos quais os homens mantêm os termos do contrato sexual. O contrato do casamento ainda é fundamental para o direito patriarcal, mas o casamento atualmente apenas um dos caminhos sociais, dentre os aceitáveis, para homens terem acesso sexual aos corpos das mulheres (PATEMAN, 1993).

Ainda de acordo com Pateman (1993), existe um comércio estabelecido para oferta de corpos femininos. A prostituição é integrante do arranjo capitalista. A figura da prostituta está facilmente colocada a qualquer homem que possa e queira pagar por esse serviço. A prostituição é compreendida como negócio privado, e o contrato estabelecido entre a figura do cliente e da prostituta é visto como um contrato particular entre quem vende e quem compra. As mulheres ocupavam posições determinantes e eram consideradas a encarnação terrena da Deusa, 
proporcionavam o elo vital entre a comunidade e a divindade, portanto controlavam a sua sexualidade. Eram autônomas e desinibas em sua expressão sexual.

A prostituição correspondeu a uma necessidade social em decorrência do urbanismo, a sociedade privada, o mercantilismo, a acumulação de riquezas, o pauperismo, que alteraram o ritmo natural da vida e necessariamente o das manifestações sexuais. Homens de determinadas classes, em virtude do pauperismo ou em razão de suas funções, não podiam ter uma mulher privativa. Os de outras classes, por conta de suas riquezas, poderiam dispor de muitas delas.

As prostitutas estão facilmente acessíveis para quem possa pagar por seus serviços e comumente são oferecidas ao longo da história como parte de transações comerciais, políticas e diplomáticas.

\begin{abstract}
Surgiu, então, a instituição da mulher comum, para a manutenção da qual todos concorriam com uma quantia sempre inferior à que teriam de dispender com umas ou mais mulheres permanentes e privativas. Em compensação aboliam, para elas, o tabu do exclusivismo, concedendo- lhes a faculdade de terem relações com quem quisessem. Por um tácito acordo, os habitantes da cidade, pertencente a todas as classes estabeleceu a socialização das mulheres. Feita a socialização das mulheres, por tal acordo, logo o mercantilismo aproveitou disso para negociar. (BRASIL, 1933)
\end{abstract}

Os magistrados regulamentaram o funcionamento desse negócio, proibindo que o exercessem pessoas não cadastradas. Os edis ${ }^{13}$ de Roma tinham os registros das prostitutas de cada bairro e perseguiam as que se entregavam à profissão clandestinamente. A clientela desse comércio era constituída (como atualmente) de rapazes tímidos, defeituosos, os "decrépitos" ou quase impotentes, pelos pervertidos que, numa manifestação de masoquismo, só têm prazer junto de mulheres públicas, e pelos homens relativamente normais, que não encontrando satisfação sexual junto de suas esposas procuravam obter através das sucessivas e fugazes uniões com ná

${ }^{13}$ Edis: Este cargo foi criado no séc. V a.C. Tal como era normal em Roma, tinham imensas funções, algumas delas semelhantes às de outros cargos. Organizavam festas, vigiavam a manutenção dos edificos públicos, asseguravam a qualidade dos alimentos e a sua importação em caso de dificuldade de abastecimento. 
prostitutas. As limitações de caráter religioso, moral e fisiológico mantiveram o meretrício e a socialização das mulheres, instituindo na história antiga aos dias atuais, a promiscuidade masculina e para as mulheres a submissão de seus corpos.

A prostituta, na Grécia era porné ou auletrida. Na Índia, dovadassi, quando bailadeira ao serviço de Siva, ou natché; na Babilônia, pariunstu; no Japão djyoio; e, no Egito, alimé, que significava sábia experiente e em Roma foi meretrix e prostitutae.

As meretrizes romanas exerciam sua profissão com recato, nas alcovas ou casas abobadadas; as prostitutas praticavam- na às escâncaras, às vezes, até, sem correr a cortina da cela. (BRASIL, 1933)

Conforme os locais onde faziam o seu comércio, as suas preferências, a sua anterior condição social, as prostitutas em Roma chamavam-se: alicariae, casoritae, copae, diatrolae, porariae, libtidae, noctunigitae, prosedae, pregrinae, putae, quadrantariae, seratiae, scrotae, vagae, etc. Essas mulheres, para se distinguir das demais eram obrigadas pelos edis de quem dependiam, a usar apenas a toga viril, com mitra e véus amarelos. (BRASIL, 1933)

A Igreja católica não só fomentou o meretrício como o organizou e explorou em seu proveito. A prostituição regulamentada é uma instituição católica. Os papas, soberanos temporais, soberanos espirituais fomentaram o desenvolvimento legal da prostituição. As prostitutas deveriam todos os dias assistir, muito cedo, a uma missa especial. A casa devia estar fechada na Semana Santa e pagava indultos segundo as festas da Igreja sendo mais elevadas nos "dias santos". A "senhora", depois de suas despesas todas pagas, devia dar um terço de seus lucros ao Esmoler Pontifício e outro terço ao Mordomo de Sua Santidade. O último terço era reservado à diretora, para as "despesas de seu zelo". (ROBERTS, 1998)

Cada visitante só podia escolher uma mulher de cada vez. Os quartos deviam ser hermeticamente fechados, de maneira que nenhum ruído se ouvisse exteriormente e que as vozes não pudessem chegar até os habitantes das casas vizinhas. O mesmo visitante podia apresentar-se duas vezes por dia, mas para se isolar com a mesma mulher. Os clérigos, os prelados e os monsenhores só podiam ser recebidos quando trouxessem o indulto. Um dos médicos do Papa 
devia assegurar-se da saúde das mulheres "com decência, mas com exatidão". Não podia haver lá mulher que fosse "irmã de um cardeal". A mulher, depois de pagar suas despesas, deveria dar um terço do seu ganho ao mordomo de Sua Santidade, enquanto que o último terço revertia para a diretora "em recompensa de seu zelo“. O Papa Júlio II concedeu às prostitutas um bairro especial em Roma, por Bula de 10 de janeiro de 1510. Leão X publicou três regulamentos, para salvaguardar a decência exterior e a boa ordem da confraria das prostitutas romanas. (ROBERTS, 1998)

A prostituição era cultivada na Roma pontifical e os exemplos do alto frutificavam e se multiplicavam no baixo clero. Tudo isso se fazia ostensivamente não obstante a repressão legal, o que nos tempos de hoje parece um tanto paradoxal, pois a legislação e os costumes pouco têm desenvolvido no que diz respeito. As prostitutas continuam dependendo das autoridades policiais que as prendem e soltam discricionariamente, lhes cobram taxas e impõem multas, as obrigam a viver em determinados locais e lhes proíbem o trânsito ou a permanência noutros. (ROBERTS, 1998)

\subsection{Prostituição de travestis.}

O universo da prostituição para travestis quem atuam nele se configura como um dos principais lugares que contribuem para a construção da sua identidade. Os territórios de prostituição se expressam como importantes espaços para sociabilização e aprendizado, onde a convivência contribui para que elas se ressignifiquem construindo a sua identidade de gênero feminina. É nesse mesmo lócus que são reproduzidos os diferentes valores de masculino e feminino, travestis e clientes nesse espaço compartilham compreensões de gênero semelhantes ou complementares. Essa identidade ultrapassa o campo das identidades sexuais ou de gênero, tornando-se também uma identidade profissional. (GARCIA, 2008)

Isso não quer dizer que devemos associar diretamente travestis e prostituição, mas também não podemos deixar de considerar que a expressiva ocupação delas nesse espaço. 
O que se observa é que em sua grande parte as travestis que atuam na prostituição são de baixa renda, isso denota a clara necessidade de atenção ao mercado da prostituição e seus mecanismos de vulnerabilidade, participando da atividade travestis retro-alimentam o processo histórico de incriminação a que foram submetidas em uma sociedade que não tolera aqueles(as) que rompem expectativas de gênero hegemônicas. (GARCIA, 2008)

O gênero performático de acordo com Judith Butler nega características que fixam e estabilizam a identidade. Tendo a identidade de gênero como construída socialmente, esse processo não se dá de maneira única, onde sujeitos somente reproduzem discursos sociais préestruturados. Os efeitos da compreensão de gênero refletem principalmente sobre corpo e os atos provenientes dele, dessa maneira o corpo não pode ser considerado a partir de pressupostos fixos na qual a cultura imprime valores. (BUTLER, 1993)

Pensar o corpo de acordo com discursos hegemônicos exclui a existência de processos de subjetividade que são expressos pelas pessoas mediante suas vivências com as identidades de gênero. Essas são permeadas pelas relações de poder exercidas em múltiplas direções que são instituídas por toda a sociedade. (FOUCAULT, 1988) A identidade de gênero é uma representação que para existir se efetiva através dos seres em seu contexto social e nesse encontro ocorre à enunciação do ato performático do gênero.

As identidades de gênero estão sempre subjugadas de acordo com reproduções ideais da norma de gênero. Essa concepção nega que a identidade é inteiramente coordenada com as subjetividades. O gênero é compreendido para além das representações de papéis a serem desempenhados por corpos de homens e mulheres sob a hegemonia da heteronormatividade, caracteriza-se uma complexidade aberta. (ORNAT, 2008)

O preconceito é o principal responsável por produzir dificuldades para esse grupo obter melhorias de vida econômica, sempre relacionada à impossibilidade de exercer outra atividade produtiva fora da prostituição. A configuração dos espaços de prostituição travesti são a apropriação e instituição do território que se demonstra a imbricação entre corpo, sexualidade, espaço e poder. As espacialidades envolvidas são elementos fundamentais na existência do grupo, significam posições de sujeitos, compõem relações de forças e orientam suas escolhas para apreensão da realidade, tudo isso fazendo parte da significação da identidade de gênero. (ORNAT, 2008) 
O território da prostituição travesti tem como um de seus elementos estruturantes a comunicação tanto entre travestis como entre elas e clientes, policiais, moradores de rua e demais grupos sociais. Dessa maneira, expondo uma relação direta entre corpo e espaço. O segmento das travestis se depara com táticas para sobrevivência que transformam o segredo por trás de seus corpos em segregação, em decorrência disso são silenciados e se colocam diante do caminho da politização convertendo gueto em território e estigma em orgulho. (LOURO, 2001)

A existência das travestis é marcada por uma diversidade de ameaças, que podem ser assaltos, brigas, rivalidades, violência, drogas e discriminação. Essas ações se dão pelas travestis serem consideradas anormais por não pertencerem à sociedade que tolera apenas prostitutas que são mulheres biológicas do gênero feminino e heterossexuais.

\section{Metodologia.}

Tendo metodologia como o conjunto de abordagens, técnicas e processos utilizados pela ciência para formular e resolver problemas de aquisição objetiva do conhecimento de maneira sistemática, a pesquisa realizada levantou aspectos teóricos, metodológicos, empíricos e práticas acerca da prostituição de travestis.

O tipo de pesquisa realizada atende ao modelo exploratório e social. O objetivo inicial foi a caracterização do problema, sua classificação e sua definição. A ação era de constatar a pergunta do presente trabalho a partir do fenômeno, bem como proporcionar maior familiaridade como problema, realizar levantamento bibliográfico e entrevistas a partir dos casos pesquisados por meio de entrevistas.

O procedimento utilizado foi levantamento de dados por meio de pesquisa de campo, nesse momento se deu a observação dos fatos tal como ocorrem sem permitir isolar e controlar variáveis, mas perceber e estudar as relações estabelecidas.

O objeto foi compreendido pela perspectiva bibliográfica e de campo, a abordagem utilizou a técnica estritamente qualitativa, de maneira a obter informações que não poderiam ser quantificáveis, os dados foram obtidos indutivamente e a interpretação dos fenômenos e a atribuição dos significados são básicas nesse processo. Os estudos realizados foram transversais 
à temática, os indivíduos foram descritos de acordo com relação às suas características pessoais e suas historias de exposição a fatores causais suspeitos. Os dados utilizados foram primários, onde as variáveis levantadas foram observadas pela própria pesquisadora.

O método apreendido para a realização da pesquisa foi o materialismo histórico-dialético, partindo do pressuposto de que a dialética busca levantar pontos críticos acerca da realidade. $\mathrm{O}$ maior objetivo era trazer a reflexão para as travestis de porque trabalho e exploração para elas se encontravam em espaços distintos. As questões levantadas não foram analisadas na qualidade de objetos fixos. Nesse método, os fenômenos não devem ser compreendidos isoladamente. A dialética é um método de pesquisa que busca a verdade por meio de formulação adequada de perguntas e respostas, até atingir o ponto critico do que pode ser falso ou verdadeiro, tendo como objetivo primordial problematizar a realidade de forma critica. O método dialético se expressa por meio do questionamento argumentativo.

Portanto, os procedimentos para a execução da coleta de dados e operacionalização do presente Trabalho de Conclusão de Curso (TCC) seguiram a seguinte ordem cronológica exposta abaixo:

a) Fontes Documentais: arquivos históricos, registros estatísticos, relatórios institucionais, legislações vigentes e documentos de comunicação de massa (internet); que consistiu no levantamento bibliográfico;

b) Analise e coleta dos dados: produzida por entrevistas realizadas no SCS de Brasília, mediante questionários pré-elaborados ${ }^{14}$;

c) Estudo de Caso: os dados são coletados sob condições de ambiente não controlado, isto é: em contexto real, cujo a fonte das evidencias é o registro em arquivo das entrevistas, que permitiu construir a Historia de Vida das travestis;

d) Elaboração do Estudo de Caso: A partir da elaboração dos questionários propostos foi dado o tratamento mais detalhado se configurando em histórias de vida que constituíram dados relevantes para as conclusões deste trabalho;

ná

${ }^{14}$ Precisar o contingente exato de travestis é complicado. Muitas ainda estão nessa transição de ressignificação do gênero, portanto nos dias presentes foram realizados os quest 


\subsection{Método.}

O método escolhido para análise do objeto de estudo é o materialismo histórico-dialético. A dialética que aparece no pensamento de Marx surge como tentativa de superação da dicotomia, da oposição entre sujeito e o objeto. A dialética tem suas primeiras expressões na Grécia Antiga, sendo chamada de arte do diálogo. Sócrates utiliza esse conceito para desenvolver sua filosofia. A verdade é atingida pela relação de diálogo que pressupõe minimamente duas instâncias, mas até aqui o diálogo acontece sob um princípio de identidade, entre os iguais. A diferença se constitui na contrariedade e no conflito. Não é a concórdia que conduz ao diálogo, mas a divergência, isto é, a exacerbação do conflito. (NOVELLI E PIRES, 1996)

A partir de então já se afirmava que a lógica dialética é uma possibilidade de compreensão da realidade como essencialmente contraditória e em permanente transformação (Konder, 1981), em contraposição à lógica formal, estática, que não aceita a contradição e o conflito. No Renascimento, a busca da objetividade levou o pensamento humano a uma profunda separação entre sujeito e objeto e ao abandono do pensamento dialético como lógica de interpretação do mundo e como objeto de estudo das ciências e da filosofia. No entanto, observase que a base de compreensão da dialética, a contraditoriedade e movimento do mundo.

Partindo das idéias de Kant (1724-1804) sobre a capacidade de intervenção do homem na realidade, sobre as reflexões acerca do sujeito ativo, Hegel tratou da elaboração da dialética como método, desenvolvendo o princípio da contraditoriedade afirmando que uma coisa é e não é ao mesmo tempo e sob o mesmo aspecto. Esta é a oposição radical ao dualismo dicotômico sujeito-objeto e ao princípio da identidade. Por isso Hegel preconiza o princípio da contradição, da totalidade e da historicidade. (NOVELLI E PIRES, 1996)

O teórico Karl Marx, filósofo, economista, jornalista e militante político, em suas construções teóricas se viu em busca de um caminho epistemológico ou de uma corrente que fundamentasse o conhecimento para a interpretação da realidade histórica e social que o desafiava. Nesse processo superou as posições de Hegel no que dizia respeito à dialética e conferiu-lhe um caráter materialista e histórico. Para o pensamento marxista, o que importa é descobrir as leis dos fenômenos de cuja investigação se ocupa, o que importa é captar 
detalhadamente as articulações dos problemas em estudo, analisar as evoluções e rastrear as conexões sobre os fenômenos que os envolvem. (PIRES, 1997)

A separação sujeito-objeto, promovida pela lógica formal, não satisfazia a Marx e a Hegel que na busca da superação desta separação, partiram de observações acerca do movimento e da contraditoriedade do mundo, dos homens e de suas relações. A lógica formal não consegue explicar as contradições e amarra o pensamento impedindo-lhe o movimento necessário para a compreensão das coisas. Se o mundo é dialético (se movimenta e é contraditório) é preciso um Método, uma teoria de interpretação, que consiga servir de instrumento para a sua compreensão, e este instrumento lógico pode ser o método dialético tal qual pensou Marx. O método dialético que desenvolveu Marx, o método materialista histórico dialético, é método de interpretação da realidade, visão de mundo e da prática articulada à teoria. (PIRES, 1997)

Marx compreendia que Hegel trata a dialética idealmente, no plano do espírito, das ideias, enquanto o mundo dos homens é preciso sua materialização. Tendo isso em mente, Marx deu o caráter material e o caráter histórico quando passou a analisar a organizam dos seres na sociedade para produção e reprodução da vida e como eles vêm se articulando para isso no desenvolvimento da história. É em $O$ Capital, sua mais importante obra, que encontraremos não uma exposição do Método, mas sua aplicação nas análises econômicas ali empreendidas. A Contribuição à Critica da Economia Política, texto introdutório de $O$ Capital, talvez seja o texto de Marx que mais se aproxima de uma sistematização do Método. (PIRES,1997)

O método materialista histórico-dialético caracteriza-se pelo movimento do pensamento através da materialidade histórica da vida dos homens em sociedade, isto é, trata-se de descobrir (pelo movimento do pensamento) as leis fundamentais que definem a forma organizativa dos homens durante a história da humanidade. O princípio da contradição, presente nesta lógica, indica que para pensar a realidade é possível aceitar a contradição, caminhar por ela e apreender o que dela é essencial. Neste caminho lógico, movimentar o pensamento significa refletir sobre a realidade partindo do empírico (a realidade dada, o real aparente, o objeto assim como ele se apresenta à primeira vista) e, por meio de abstrações (elaborações do pensamento, reflexões, teoria), chegar ao concreto: compreensão mais elaborada do que há de essencial no objeto, objeto síntese de múltiplas determinações, concreto pensado. (PIRES, 1997) 


\section{Apresentação e analise do objeto de estudo.}

\subsection{Prostituição.}

Analisando a prostituição é possível destacar que ela está colocada por meio de dois fatos. Ela se baseia na desigualdade de gênero e nas desigualdades socioeconômicas, étnicoraciais e geracionais. Esses pilares são revelados pelo universo das pessoas prostituídas geralmente de baixo nível socioeconômico. Os que podem ser demarcados pela expressividade como consumidores da prostituição são homens, geralmente adultos, brancos, heterossexuais ou bissexuais, além de possuir recursos e utilizá-los para compra do sexo, para satisfazer sua necessidade, fantasia ou desejo. (FIGUEIREDO e PEIXOTO, 2001)

Esse processo também está constantemente associado ao tabu presente na sexualidade. Argumentos que se explicam a "notória" sexualização de quem se prostitui têm sido utilizados como fator para afirmar que a atividade é uma escolha de profissão (a chamada vida fácil). A atual sociedade não tolera tais expressões e as relega à marginalidade, privilegiando e promovendo apenas a monogamia, a matrimonialidade e a sustentação da estrutura familiar no modelo burguês-europeu. (FIGUEIREDO e PEIXOTO, 2001)

A desigualdade social das pessoas que se encontram nessa atividade causa invisibilização que se fundem as noções de autoritarismo e supremacia entre as classes. Isso resulta em uma série de vulnerabilidades: expulsão e abandono pela família, à necessidade de busca de autosustento que irá expô-lo à homofobia e à violência e a ocorrências de saúde.

O desemprego está associado indiscutivelmente à venda do corpo. A prostituição por ser um negócio de homens, onde o Estado e a classe dominante - o homem - assentam o seu poder e os seus recursos econômicos sobre a exploração de seres. A prostituição constitui um claro expoente do machismo. A prostituição é o símbolo mais tangível da ditadura heterossexual da nossa sociedade: o macho impõe o seu desejo em troca de dinheiro. A superioridade econômica lhe permite assegurar os serviços de quem se prostitui. (SOF - Folha Feminista, 2003) 
A prostituição se caracteriza como solução temporária à espera de um trabalho regular. Entretanto, à falta de qualificação profissional para a entrada no mercado, a prostituição permanece como a única possibilidade de sobrevivência. O campo de atuação tem se expandido ao passo que meios de comunicação estimulam propostas de serviços, por meio de anúncios em jornais/revistas, televisão, telefone ou internet. O que se observa é a prostituição se adaptando às novas demandas do mercado. (CECCARELI, p. 5, 2008)

Quem se prostitui está no espaço de sujeitos estigmatizados e em situações de vulnerabilidades, sendo assim quem compra encarna a possibilidade de uma sexualidade sem entraves. O sistema de valores que sustenta a família burguesa determina a moral sexual vigente, os espaços de prostituição se colocam como opostos a noção de lar. Os dois espaços são inconciliáveis; quem freqüenta um, não pode ser visto no outro. (CECCARELI, 2008)

A prostituição traz a marca de um estigma relacionado a comportamentos e práticas sexuais marginais, por outro lado, é justamente dessa marginalidade que ela tira sua força. O território de prazeres ilegítimos, que conta com a cumplicidade entre aqueles que o freqüentam, permite ao homem viver fantasias sexuais inconfessáveis, sem se sentir ameaçado em sua identidade social. Existem também aqueles para quem o pagar representa uma forma de afirmação de poder e virilidade. (CECCARELI, p. 9, 2008)

Quem atua na prostituição obviamente não existe sem ter quem compre. Entre eles há um movimento mútuo e complementar de oferta e demanda. É por existirem e complementarem desejo com necessidade que a prostituição continua a existir. A legislação penal brasileira não criminaliza a prostituição, por entender que ela não é um problema penal, mas social. Nem quem se prostitui nem clientes incorrem em penas. 
O Capítulo V do Código Penal, porém, considera crime punível com prisão induzir ou atrair alguém à prostituição, ou, ao contrário, impedir alguém de abandoná-la; criar ou manter casas ou locais para encontros libidinosos, havendo ou não intuído de lucro; tirar proveito da prostituição alheia; intermediar a entrada, o transporte, a transferência ou acolhimento no território nacional de pessoas que venham exercer a prostituição; facilitar a saída de pessoas para exercê-la no exterior. (CECCARELI, p.20, 2008)

\title{
4.2. Prostituição e Exploração.
}

Acompanhamos o crescente agravamento das contradições sociais decorrente da construção histórica, onde múltiplas determinações presentes na ordem capitalista contribuem para a miséria material e humana. Seres são cada vez mais fragmentados (as) e impedidos (as) de se perceberem em suas totalidades, não se vendo em sociedade como sujeito histórico e social. O capitalismo tem em sua reprodução social duas determinações originais: produção e propriedade. Sob o comando do capital, o sujeito que trabalha não mais pode considerar as condições de sua produção e reprodução como sua própria propriedade. (PIRES, 2004)

\begin{abstract}
Elas não mais são os pressupostos autoevidentes e socialmente salvaguardados do seu ser, nem os pressupostos naturais do seu $e u$ como constitutivos da "extensão externa de seu corpo". Ao contrário, elas agora pertencem a um "ser estranho" reificado que confronta os produtores com suas próprias demandas e os subjuga aos imperativos materiais de sua própria constituição. Assim, a relação original entre o sujeito e o objeto da atividade produtiva é completamente subvertida, reduzindo o ser humano ao status desumanizado de uma mera "condição material de produção". O "ter" domina o "ser" em todas as esferas da vida. (MÉSZÁROS, 2002, p. 611)
\end{abstract}

Na prostituição essa relação é modificada, pois quem se prostitui coloca a disposição o seu corpo. Aqui o corpo se estabelece como mercadoria e o serviço que se presta através dela que pode ser definido como força de trabalho, é atribuído valor. Esse fixado de acordo por quem 
oferece, ou seja, em um balanço interior de quem se prostitui o valor sobre o seu corpo que é o que exerce a sua força de trabalho que executa os serviços sexuais prestados que se configuram como mercadoria.

Valores constituídos com base no pensamento capitalista destroem o ser, ou seja, homens e mulheres como sujeitos em totalidade. O ter passa a determinar as relações inseridas no movimento dialético entre objetividade e subjetividade. A produção da mercadoria tem raiz no acúmulo de riquezas, perpassa o valor - de - uso, estimula o consumo e a construção das relações pautada na mercantilização. A dominação permeia dois âmbitos essenciais os quais se relacionam dialeticamente. Por um lado acontece através da propriedade dos meios de produção, que se mantém e desenvolve-se a partir da exploração do trabalho e, por outro, através da propriedade da construção intelectual, ideológica. (PIRES, 2004)

Por precisar manter seus meios de subsistência, travestis oferecem o seu corpo transfigurado em serviços sexuais (mercadoria) para determinar perante o qual compra o seu valor de uso, atendendo a quem demanda e construindo o mercado da prostituição. Após isso fica fácil identificar uma relação mercantil extremamente definida. As vivências de dominação se manifestam nas duas esferas: quem oferta precisa vender sua mercadoria munida de valor de uso, quem demanda compra porque demanda esse "bem". Nesse caso pode-se dizer que a travesti por possuir o seu corpo detém o meio de produção, mas na realidade a construção histórica deixa bem claro que corpos sempre foram submetidos à lógica machista - capitalista. São corpos que os seres os têm, mas que são dependentes dos desejos de outrem.

As pessoas estão constantemente sofrendo influências no âmbito estrutural, político, econômico e questões do campo ideológico. Isso se justifica porque não é possível desvencilhar as relações sociais da construção ideológica das forças produtivas. Quem detém os meios de produção acumulou riquezas, às outras pessoas restou vender "sua pele", não sendo possível vender nada mais além de si mesmo. A produção de mercadoria depende da força de trabalho humana. Quem compra a força de trabalho a consome ao fazer trabalhar quem a vende. (PIRES, 2004)

A mercadoria como objeto palpável, sensível, atende a necessidades específicas. A qualidade desse uso potencial Marx denomina valor de uso. Portanto, o valor de uso corresponde à esfera qualitativa da mercadoria. Independentemente de seus valores de uso, as mercadorias são 
intercambiáveis entre si. A capacidade dessas mercadorias de trocarem-se umas pelas outras induz a pensar que há nelas uma propriedade comum, um fator quantitativo geral e impalpável. Essa propriedade genérica das mercadorias recebe o nome de valor de troca ou, simplesmente, valor. (MACHADO, 2007)

Atendendo totalmente à compreensão qualitativa que os serviços sexuais atendem, a venda desses determina o seu valor de uso. No caso das travestis que se prostituem o valor da mercadoria que produzem é trocado diretamente pelo dinheiro.

\begin{abstract}
O valor de uma mercadoria refere-se às suas relações de troca, sendo independente de suas características físicas, geométricas ou de qualquer outra natureza. Nesse sentido, o valor de troca encontra-se na exterioridade do valor de uso. Colocam-se de lado os valores - de - uso das mercadorias, quando se trata da relação de troca entre elas. Os valores de troca referem-se a padrões meramente quantitativos, enquanto os valores de uso, posto que inseridos na esfera qualitativa, são irredutíveis uns aos outros. (Marx, 2002, p. 59.)
\end{abstract}

O valor de uma mercadoria corresponde à quantidade de trabalho nela armazenado. Uma mercadoria qualquer, para ser potencialmente "trocável", deve atender a alguma necessidade social e, portanto, ter valor de uso para alguém. Entretanto, o valor de uso vigora, dessa maneira, como um mero índice da possibilidade de troca entre as mercadorias. Os produtos do trabalho tornam-se, em sua forma fenomênica, por sua vez, os depositários das relações sociais de que eles originariamente resultam. Os produtores são substituídos pelas mercadorias em sua movimentação social. (PIRES, 2004)

O valor da mercadoria oferecida pelas travestis que atuam na prostituição atende diretamente a uma necessidade social. Em nossa sociedade apesar de mal vista, os índices de pessoas que se prostituem são bastante expressivos. A atividade é pejorativa mas o seu fim que é a satisfação dos desejos de quem compra parece ser justificável, quando alguém utiliza esses serviços sexuais está trocando por dinheiro. 
Como ocorre com toda mercadoria, o valor da força de trabalho equivale ao tempo de trabalho nela corporificado. Dessa maneira, a conservação e a reprodução da força de trabalho correspondem à manutenção do corpo vivo do seu proprietário, ou seja, do trabalhador. Para sustentar-se, todo indivíduo necessita de uma quantidade mínima de meios de subsistência. O mínimo valor da força de trabalho é dado pelo valor dos meios de subsistência imprescindíveis ao ser humano. (PIRES, p. 9 e 10, 2004)

\subsection{Prostituição e Trabalho.}

A luta social e política em torno dos modelos e soluções para o campo da prostituição é intensa, envolvendo organizações internacionais, governos, partidos políticos, movimentos feministas e coletivos de defesa de quem atua na atividade. Com posicionamentos políticos e objetivos muito diferentes, a divisão entre eles faz-se segundo dois eixos: da sexualidade, no qual se coloca a relação entre libertação e repressão; da ordem política e social no qual se coloca o caráter da emancipação e do poder sobre o próprio corpo. Partindo do pressuposto de que a prostituição pode ser compreendida nas dimensões social, econômica e política, considera-se que ela serve para satisfazer necessidades sexuais e manter e exprimir a dominação de quem compra por quem oferece, vista nesse âmbito como simples objeto sexual comercializável. (BESSA RIBEIRO, 2008)

A análise de Marx sobre o desenvolvimento do sistema capitalista permite criar três formas sucessivas e interdependentes: mercadoria, dinheiro e capital. O capital supõe a subordinação do processo de reprodução social que possui os sujeitos humanos, transformando-os em meros suportes da vida social dos produtos do seu próprio trabalho. (BESSA RIBEIRO, 2008) 
No ano 2002 que a prostituição foi incluída na Classificação Brasileira de Ocupações (CBO), que é o documento que reconhece, nomeia e codifica as ocupações existentes no mercado brasileiro (MINISTÉRIO, 2008). "Profissionais do sexo" foram entrevistados (as) respondendo sobre o que fazem o que é distintivo de sua profissão, o nome usado e o mercado de atuação. Essa inclusão não foi fruto de um movimento específico, mas foi influenciada pelas discussões em torno da prostituição enquanto um trabalho, feitas por organizações de prostitutas.

A ocupação é vista como parte da vida das pessoas e não como única atividade definidora de sua identidade. Neste sentido, Fonseca (1996), afirma que nem sempre a prostituição ocupa lugar central na vida dessas pessoas e destaca a existência de uma grande diversidade de pessoas que se prostituem que podem variar segundo a idade, objetivos, estado civil, entre outros.

A CBO traz uma descrição sumária das ocupações, que seriam designadas as pessoas que se prostituem:

\begin{abstract}
Batalham programas sexuais em locais privados, vias públicas e garimpos; atendem e acompanham clientes homens e mulheres, de orientações sexuais diversas; administram orçamentos individuais e familiares; promovem a organização da categoria. Realizam ações educativas no campo da sexualidade; propagandeiam os serviços prestados. As atividades são exercidas seguindo normas e procedimentos que minimizam as vulnerabilidades da profissão (MINISTÉRIO, 2008).
\end{abstract}

De acordo com essa mesma legislação, profissionais do sexo precisam seduzir o cliente, manter relações sexuais, representar papéis, inventar estórias, negociar o preservativo, entre outras. Obviamente, nem todas as prostitutas realizam cada uma dessas atividades, sendo que algumas podem atuar, por exemplo, apenas acompanhando clientes. A variedade de atividades evidencia ainda a existência de um saber fazer próprio à profissionais do sexo. Podemos observar assim uma grande variedade de visões das próprias mulheres sobre o que é ser prostituta e o que é a prostituição. Ficam evidentes também os inúmeros significados que são atribuídos a ocupação. (BARRETO, 2008) 
A prostituição muitas vezes é uma opção de trabalho mais flexível, melhor remunerada e com jornada de trabalho mais curta do que outras atividades. Propiciam renda não só para as prostitutas e para suas famílias, mas para os inúmeros envolvidos na atividade, por vezes bastante organizada, sofisticada e diversificada. Como qualquer trabalho, gera lucro e emprego, mas acaba por não permitir o acesso a direitos, devido a avaliações feitas por critérios morais, sociais ou econômicos. (BARRETO, p. 51, 2008)

É complexo descrever a prostituição em conceitos restritos. Muitos movimentos de prostitutas têm buscado uma visão da prostituição como um trabalho e, como tal, sujeito a explorações. Compreender o trabalho sexual como passível de exploração, tal qual qualquer outro trabalho, pode implicar em bases para a mobilização e lutas por melhores condições de trabalho, direitos e benefícios, bem como para a resistência à opressão, permitindo o surgimento de estratégias para a busca por mudanças. (KEMPADOO, 1998)

O que é construído atualmente nas organizações é que a prostituição deve estar circunscrita no campo da discussão da cidadania. O que se busca destacar é que a atividade esteja relacionada a direitos sexuais e trabalhistas, não ao entendimento criminal e penal. $O$ ponto principal é estimular iniciativas concernentes ao campo do reconhecimento de direitos e da identidade de quem atua na atividade. A principal preocupação é no campo da saúde (Doenças Sexualmente Transmissíveis e HIV/AIDS), mas se deve ir além possibilitando a abertura de diálogo com outros setores como trabalho, da justiça, do turismo e do legislativo. (TEIXEIRA RODRIGUES, 2009)

\subsection{Travestis que atuam na Prostituição em Brasília.}

Travestis em espaços sociais que atendem normas pré-estabelecidas estão relacionadas à registros que ameaçam. A presença delas em lugares públicos particularmente durante o dia resulta em reações violentas, portanto muitas delas têm na noite o espaço de livre exercício da sua identidade. De acordo com MacDowell (2008) a personagem de sua pesquisa chamada Laura (nome fictício), travesti que mora em quarto alugado situado a poucas quadras do SCS (local 
onde se prostitui) relatou que há alguns anos não realiza compras no supermercado localizado próximo a sua casa. Ela contou que da última vez em que esteve no recinto foi revistada por um segurança que a acusara de furtar um produto. No determinado dia alguns (algumas) clientes da loja a agrediram com insultos. Não foi a primeira vez que se sentiu constrangida em um espaço público e a solução que encontrou foi pagar alguém que se disponha a realizar as compras do que necessita.

$\mathrm{O}$ autor cita que o caso de Laura é apenas um recorte, mas muitas outras relataram histórias de constrangimentos vividos em ônibus, lojas, hospitais e postos de saúde, delegacias, escolas e espaços públicos. Muitas delas ainda evitam sair de casa no período matutino ou freqüentar lugares movimentados. Isso nas dá margem a interpretar que podemos até vê-las, desde que em seu espaço designado, ou seja, no período da noite associada à prostituição. (MACDOWEEL, 2008)

É expressivo o número de travestis que não atingindo a inserção em empregos "formais", são atraídas pela possibilidade de bons rendimentos na "pista", bem como pelas redes de sociabilidade que se formam entre travestis que se prostituem recorrem à prostituição como meio de sobrevivência.

O caráter "ditatorial" da prostituição como imposição, aludido por Paula, é destacado pela associação generalizada feita pelo senso comum entre a condição de travesti e a prostituição. Some-se a isso que desde 2002 o próprio Ministério do Trabalho e Emprego (MTE) traz em sua Classificação Brasileira de Ocupações as categorias "travesti" e "transexual" como sinônimas de "profissional do sexo". (MACDOWELL, p.6, 2008)

O SCS em Brasília se caracteriza como um dos principais pontos de prostituição de travestis na cidade, sendo o principal no Plano Piloto. O SCS situa em área privilegiada de Brasília, localizado no centro da cidade, com acesso pelo Eixo Monumental, a principal avenida da cidade, onde estão situadas as sedes dos principais órgãos administrativos do Brasil. Como exposto nesse trabalho os espaços de prostituição se configuram como importantes espaços de 
sociabilização e é nesse local que as travestis constroem suas identidades. A presença noturna das travestis no SCS atribui ao lugar à característica de "sujo" aos olhares da sociedade hegemônica. (MACDOWEEL, 2008)

\begin{abstract}
Em uma das ruas que dá acesso ao Setor Comercial, no vizinho Setor Hoteleiro Sul, um muro pintado com grandes letras vermelhas alerta: "Perigo, AIDS", "Cuidado, HIV", "Preserve-se, AIDS". A doença, automaticamente associada aos corpos de travestis, opera aqui como signo do impuro, marca de temor e desprezo, que marginaliza, exclui, reprime e, em casos extremos, extermina os grupos e indivíduos identificados com o lugar da abjeção. É a senha para que o domínio da violência se instale naquele espaço de forma legitimada, como ato purificador. (MACDOWELL, 2008)
\end{abstract}

Como em muitos espaços de prostituição que são marcados pela violência o SCS não se diferencia nisso. O local tem um extenso histórico de agressões contra travestis, incluindo atos de violência sexual, violência física, extorsão, associação com cafetinas e cafetões que exploram o trabalho sexual. A Secretaria de Segurança Pública juntamente com a Polícia Militar e Civil, Corpo de Bombeiros e Juizado de Menores coordenaram várias atividades no ano de 2007 intituladas "arrastões", o objetivo dessas ações são de "moralizar" a área. O que travestis relatam é que quando chegam às delegacias regionais elas são despidas, revistadas intimamente e constantemente agredidas (MACDOWELL, 2008)

Em pesquisa quantitativa realizada no ano de 2005 pelo Estruturação - Grupo Homossexual de Brasília, foram levantados aspectos sobre situação sócio - econômica, violências sofridas, cidadania e prevenção de DST/AIDS na população de transgêneros profissionais do sexo que trabalham em espaços públicos do Distrito Federal. As localidades aplicadas foram SCS e na Ceilândia (região administrativa de Brasília).

O principal aspecto levantado na pesquisa é que das pessoas que entrevistadas $78 \%$ se identificaram enquanto travestis. Esse dado respalda o que tem sido exposto no presente trabalho, a maior parte de quem está em espaços de prostituição são travestis. Quando perguntadas se têm intenção de sair da atividade da prostituição, $72 \%$ entrevistadas afirmaram 
que sim e os motivos são porque considera perigoso, não vêem futuro e não gostam de se prostituir.

\subsection{O que as travestis pensam da prostituição? É trabalho ou exploração?}

Para a identificação desse objeto de pesquisa foram realizadas entrevistas com travestis que se prostituem ou já se prostituíram nas imediações do SCS. O objetivo do levantamento qualitativo era questionar a percepção delas sobre a prostituição, se consideravam trabalho ou exploração. As entrevistas foram levantadas em dois momentos: 1)Realizadas conjuntamente com a atividade de prevenção e distribuição de preservativos e gel lubrificante desempenhada pelo Estruturação por meio da profissional Soninha Moraes, 2) Levantadas no II Seminário da Visibilidade de Travestis e Transexuais do Distrito Federal por meio da presidente da ANAV Trans Charlotte da Matta.

Não é possível precisar quantas travestis se encontram na atividade da prostituição atualmente, igualmente levantar a questão do presente trabalho foi dificultado. Realizar um questionamento como esse necessita tempo hábil para que elas reflitam sobre o que essa pergunta implica na atividade que exercem ou exerceram. Algumas entrevistas foram realizadas em espaços de prostituição, ou seja, nos pontos onde elas esperavam clientes e em regiões em que não é possível demorar muito para realizar esse levantamento. O segundo momento de levantamento realizado no seminário foi possível ter mais tempo para a reflexão. Uma estratégia de defesa de travestis é não dialogar com quem não conhecem ou não confiam, para que a pesquisa fosse efetivada foi necessário estar acompanhada de figuras reconhecidas por elas.

Em entrevista realizada com Stéfanie, 27 anos, no SCS, ela relata: Eu não posso dizer que prostituição é exploração. Eu ganho meu dinheiro com o meu corpo, eu tô aqui porque eu

quero, ninguém me forçou. É por isso aqui que eu ganho tudo que eu preciso, se eu tenho algum problema sou eu que resolvo. Ninguém ganha dinheiro em cima de mim, não tenho cafetão nem cafetina. O dinheiro que eu ganho é só meu. 
A realidade da Stéfanie é uma das expressões da prostituição entre travestis, mas existem as que são agenciadas por cafetões e cafetinas. Algumas delas deixam a entender que existe essa relação entre agenciador (a) e agenciada, mas não relataram situações de violência. Tifany coloca que tem alguém que a protege e que ela considera até proveitoso: Aqui é cheio de pivete, se você não se protege tomam tudo. Eu sei me proteger, quem tá nessa vida tem que saber e a gente sabe onde ta, tando aqui tem que tá preparada pra tudo. Tem um pessoal aí que protege a gente, que protege algumas mas não é com todo mundo. Eu não considero prostituição exploração não. Eu ganho meu dinheiro e faço dele o que eu quiser, eu sei quanto ganho e sei quanto eu to gastando. Sou dona do meu nariz.

Sissy Kelly, 53 anos, prostitui-se em toda região Sudeste, Centro-Oeste, Nordeste, Sul e alguns países da Europa. Ao ser questionada ela diz que no início a gente se considera trabalhadora, com o passar do tempo a gente se considera explorada porque todo mundo vem nos explorar no dia a dia. A gente é explorada pelas pessoas que nos alugam casas, pelas cafetinas, taxistas da noite, dono de boate. Eles pensam que a gente ganha um dinheiro fácil e a gente é explorada pelos cafetões, nos locais de prostituição aqui no Brasil e lá fora.

Cindy, 24 anos, se prostitui a 6 anos e diz que sou trabalhadora porque eu faço meus horários, faço o que eu quero nos dias em que eu quero. Pago as minhas contas, trabalho em outras coisas quando preciso e a prostituição ajuda.

Ellen relata que se prostitui a 12 anos porque eu adotei a prostituição como profissão, ninguém me chamou eu que quis ir. Consegui todas as minhas coisas pela prostituição e não me envergonho. Não tenho cafetina e eu que cuido do meu dinheiro.

Assley, 24 anos se prostitui a 4 anos eu escolhi esse caminho, eu trabalho com outras coisas fora a prostituição e eu só faço isso como dinheiro extra, quando me oferecem. Nunca me senti explorada porque eu faço quando quero.

Charlotte, 46 anos se prostituiu 25 anos : fui trabalhadora, explorada nunca. Eu optei ganhar a ganhar a vida na prostituição, nunca me senti explorada. Me senti explorada um pouco pela sociedade, mas por cafetina e cafetão ou polícia nunca, nunca dei oportunidade.

Jennifer, 37 anos a uns 10 anos atrás quando eu tinha salão eu tive muita proposta e fiz algumas vezes pra completar dinheiro. Me senti trabalhadora quando eu cuidei do meu 
dinheiro e as vezes me senti explorada quando eu tive que pagar rua, pagar ponto que tem gente que exige né?!

Michelly, 27 anos, sempre trabalhei do jeito que pude. De vez em quando consigo umas outras coisas, mas to sempre por aqui porque é dinheiro certo né?! Aqui eu consigo um dinheiro que dá pra arrumar a vida. Eu tô vendo como um trabalho como outro qualquer, venho pra cá me divirto, encontro minhas amigas e quando eu não quero mais eu vou pra casa.

Tatyana, 29 anos, é tranqüilo, to com as minhas amigas. Eu cuido de mim e vou ganhando o meu dinheirinho. A gente sofre umas coisa de vez em quando, é chato, quem tá na rua a noite é difícil, mas mesmo assim eu tô conseguindo o que eu quero. Eu to trabalhando, vejo como trabalho mesmo. Ninguém me explora porque todo o dinheiro que eu ganho usando o meu corpo, quem ta pagando paga pra mim.

Anny, 30 anos, trabalhadora ué, to pagando meus peitos e tudo que eu quero fazer com o dinheiro eu consigo aqui. Eu tô aqui por eu quero, minha família, minha mãe sabe que eu tô aqui e ela me aceita do jeito que eu sou. Esse ponto que eu tô porque eu que escolhi, de vez em quando a gente conversa aí com o pessoal que fica por aqui e tá tudo certo. Tenho muitos clientes e tô trabalhando igual muita gente que ta aí.

Cláudia, 25 anos, trabalho de secretária numa empresa conhecida durante o dia, nem posso ficar falando o nome porque você sabe como é. Tô aqui de cara limpa, trabalho aqui sem medo, sou respeitada pelas outras. De manhã eu trabalho lá e a noite eu trabalho aqui, nunca me senti explorada de jeito nenhum por ninguém. 


\section{Considerações Finais.}

Como constatado nas entrevistas, a maior parte das travestis que atuam na prostituição se consideram trabalhadoras. Quando se discute prostituição, a questão não é determinar o que é trabalho ou o que é exploração. Na sociedade do capital não existem possibilidades de trabalho que não sejam exploradas. De acordo com a construção histórica abordada, a construção capitalista estará sempre submetendo à sua lógica a força de trabalho em qualquer expressão que assuma.

A prostituição é mais uma dessas expressões fundamentadas pela lógica perversa do capital, onde todos os mecanismos se aproveitarão dos corpos em todas as suas esferas para um único fim, movimentar mercado. Conforme o discutido, quem atua na prostituição oferece serviços sexuais para quem necessita deles. Transformando para uma relação de mercado, a travesti que se prostitui oferece serviços sexuais que se configuram como mercadoria. Isso tem valor de uso para quem demanda, por isso está circunscrito na relação de compra.

A escolha do objeto de pesquisa ser as travestis se deve à escassa produção teórica sobre o segmento. Não é possível ignorar que atualmente elas são o grupo mais expressivo na atividade, sendo submetidas a inúmeras situações de violência.

$\mathrm{Na}$ "pista" elas estão sujeitas à agressão de outras pessoas que dividem os territórios de prostituição, a polícia as relaciona diretamente à marginalização dos espaços, nas instituições do Estado (saúde, trabalho e assistência social) elas são submetidas à invisibilidade, todas essas ações sendo assistidas pela sociedade que totalmente alheia ignora a cidadania do grupo.

Retomando: Não é possível pensar relação de trabalho em qualquer atividade que se exerça na sociedade do capital sem que esse seja explorado. Isso se justifica porque o preço pago pela força de trabalho e as mercadorias que ela possa produzir, é determinado por meio de valores morais construídos socialmente. Transportando para a compreensão que o trabalho aborda, quem oferece serviços sexuais tem seu corpo localizado no espaço do "mundano". Ao oferecer seu corpo para satisfação de desejos sexuais de outrem, essas pessoas são compreendidas como sujas, pois o sexo está constantemente associado à construção obrigatória dos afetos. Quando nessa relação sexual não existe essa relação de afetividade embutida, oferecer seu corpo para que outro o utilize sexualmente está fincado a noções de não respeito próprio onde você está à mercê dos 
desejos de outrem. Além disso, ainda receber dinheiro por isso a compreensão é de que não se tem escolha.

Para além de toda a construção histórica já colocada de subjugação dos corpos à lógica de dominação masculina heterossexual, entender prostituição como trabalho pode até ser possível. A questão central é de que ofertando a sua força de trabalho em espaços formais ou marginalizados não é possível desvincular de que todos e todas estarão reféns do que o capital produz para si enquanto valor. 


\section{REFERÊNCIAS BIBLIOGRÁFICAS}

ALTHUSSER, Louis. Aparelhos Ideológicos de Estado: nota sobre os aparelhos ideológicos de Estado (AIE); tradução de Walter André Evangelista e Maria Laura Viveiros de Castro: introdução crítica de José Augusto Guilhon Albuquerque. - Rio de Janeiro: Edições Graal, 1985, 2a edição.

ANJOS, Gabriele dos. Identidade sexual e identidade de gênero: subversões e permanências. Sociologias, v.2, n. 4, jul./dez. 2000, p.274-305.

BARRETO. Letícia Cardoso. Prostituição, gênero e sexualidade : hierarquias sociais 2008 e enfrentamentos no contexto de Belo Horizonte / Letícia Cardoso Barreto. - 2008

BEHRING, E.; BOSCHETTI, I. Política Social: fundamentos e história. São Paulo: Cortez, 2007 ( $2^{\mathrm{a}}$ edição).

BEHRING, Elaine.; BOSCHETTI, Ivanete. Política Social: Fundamentos e História. São Paulo. Ed Cortez. 2006

BENEDETTI, M. R. A batalha e o corpo: breves reflexões sobre travestis e prostituição. Boletín Ciudadania Sexual, Peru, v. 11, p. 5-8, 2004

BESSA RIBEIRO, Fernando. Proibições, abolições e a construção duma política inclusiva para o trabalho sexual, mestrado em Sociologia, Universidade do Minho, Braga, 16 de Fevereiro de 2008.

BOSWELL, John. Same-Sex Unions in Premodern Europe. New York: Villard Books, 1994.

BOTTOMORE, T.; HIMMELWEIT, S. População. In: BOTTOMORE, T. Dicionário do pensamento marxista. Rio de Janeiro: Jorge Zahar, 1988, p.453.

BOURDIEU, Pierre. A Dominação Masculina. Tradução Maria Helena Kühner. Rio de Janeiro: Bertrand. Brasil, 1999. 
BRASIL, Jaime. A questão sexual e o matrimônio: Erotismo e frieza. Trad. Emilia Pompéia. História da prostituição: Uma interpretação cultural. Brasil, 1933.

BOZON, M. \& GIAMI, A. (1999). Les scripts sexuels ou la mise en forme du désir presentación de l'article de John Gagnon. Actes de la Recherche en Sciences Sociales, 128.

BUTLER, J. Gender Trouble: Feminism and subversion of identity. London: Routledge, 1990.

Routledge, 1993.

Bodies that Matter: On the Discursive Limits of "Sex". New York \& London: Problemas de Gênero. Rio de Janeiro, Brasil, 2003.

CARRARA, S. \& VIANNA, A. R. B. (2006). “Tá lá o corpo estendido no chão...”: a violência letal contra travestis no município do Rio de Janeiro. Physis. Rio de Janeiro, v. 16, n. 2.

CECCARELLI, Paulo Roberto. Prostituição - Corpo como mercadoria. In: Mente \& Cérebro Sexo, v. 4 (edição especial), dez. 2008.

CORASSIN, M.L. A reforma agrária na Roma antiga. São Paulo, Brasiliense, 1988.

Código de ética do Assistente Social. Lei 8.662/93 de regulamentação da profissão. - 3. ed rer. e atual. - Brasília: Conselho Federal de Serviço Social, 1997.

DUBY, G; PERROT, M. História das mulheres no Ocidente. São Paulo, EBRADIL,1990.

DOMINGUES, Giorgia de M. Mulheres - Homens? . Fazendo Gênero 8 - Corpo, Violência e Poder. Florianópolis, 25 a 28 de agosto de 2008.

FERREIRA, Rubens da S. As "bonecas" da pista no horizonte da cidadania: uma jornada no cotidiano travesti. 2003a, 153 f. Dissertação (Mestrado em Planejamento do Desenvolvimento) Núcleo de Altos Estudos Amazônicos. Universidade Federal do Pará, 2003a. 
FERREIRA, R. S. A informação social no corpo travesti (Belém, do Pará): uma análise sob a perspectiva de Erving Goffman. Ciência da Informação. v. 38, n 2, 2009.

FOUCAULT, Michel. The Subject and Power. H. Dreyfus \& P. Rabinow (orgs.), Michel Foucault, beyond structuralism and hermeneutics. Chicago: University of Chicago Prss, 1983.

FONSECA, C. A dupla Carreira da Mulher Prostituta. Revista Estudos Feministas. Ano 4, n. 1, p. 7-33, 1996. Disponível em: http://www.portalfeminista.org.br/artigo.phtml?obj_id=807>.

Acesso em dezembro de 2008.

FOLHA FEMINISTA. Boletim da SOF na luta feminista Boletim da SOF na luta feminista junho $2003 n^{\circ} 43$ ISSN 1516-8042.

GENNARI, A.M. Duas teorias da população no pensamento clássico: Karl Marx e Thomas Maltus. In: $6^{\circ}$ Colóquio Internacional Marx e Engels, 2009, Campinas - SP. Anais do $6^{\circ}$ Colóquio Internacional Marx e Engels. Campinas : IFCH/UNICAMP, 2009. v. 1.

GOFFMAN, Erving. A representação do eu na vida quotidiana. 13. ed. Petrópolis: Vozes, 2005. (Antropologia; 8).

GORENDER, Jacob. Apresentação. In: MARX, Karl. O capital: crítica da economia política. São Paulo: Abril Cultural, v. 1, t. 1, 1983.

GRANER, Bárbara. Paper apresentado no VI Congresso Brasileiro de Prevenção das DST e AIDS - Desafios da Prevenção e da Assistência no SUS. Belo Horizonte (MG), 4 a 7 de novembro de 2006.

GRIFFIN, Susan. Livro das Cortesãs - Um Catálogo das suas Vidas. Tradução Editora Rocco, $1^{\text {a }}$ Edição - 2003.

JAYME, Juliana. Travestis, transformistas, drag-queens, transexuais: pensando a construção de gêneros e identidades na sociedade contemporânea. In: INTERCOM - Sociedade Brasileira de Estudos Interdisciplinares da Comunicação - XXV Congresso Brasileiro de Ciências da Comunicação, Salvador, 2002. 
SCOTT, Joan. Gênero: Uma Categoria Útil para a Análise Histórica. Traduzido pela SOS: Corpo e Cidadania. Recife, 1990.

KEMPADOO, K. Introduction: Globalizing Sex Workers' Rights. In: KEMPADOO, K.; DOEZEMA, J. (Ed.). Global Sex Workers: Rights, Resistance, and Redefinition. New York and London: Routledge, 1998. p. 1-28.

LUZ, M. T. O lugar da Mulher: estudos sobre a condição feminina na sociedade atual. Rio de Janeiro, Graal, 1982.

MACDOWELL, Pedro de Lemos. Geografia do gênero: do (não) lugar de travestis e outros abjetos na cidade. Trabalho apresentado no XVI Encontro Nacional de Estudos Populacionais, realizado em Caxambu, MG. Brasil. 29 de setembro a 03 de outubro de 2008. Disponível em . Acesso em 13 de setembro de 2010. p. 6.

MACHADO, Sérgio Bacchi. Marx e a crítica à história como consciência: uma confrontação com a filosofia do sujeito. Cadernos de Psicologia Social do Trabalho, 2007, vol. 10, n. 2, pp. 63-79.

MARX, K. Theories of surplus value. London: Lawrence and Wishart, 1969, 1972, 1978a. 3v.

MINISTÉRIO DO TRABALHO E EMPREGO. 2008. CBO (Classificação Brasileira de Ocupações) Profissionais do sexo. Disponível em: http://www.mtecbo.gov.br/busca/descricao.asp?codigo=5198. Acessado em 10 de junho de 2008.

O capital: contribuição à crítica da economia política. Rio de Janeiro: Editora

Civilização Brasileira, 1980, p. 80.

MOTT, Luiz R. B. Escravidão, homossexualidade e demonologia. São Paulo: Ícone, 1988.

O sexo proibido: virgens, gays e escravos nas garras da Inquisição. São Paulo: Papirus, 1988.

. A Inquisição no Maranhão. São Luís, Editora da Universidade Federal do Maranhão, 1994. 
. Memória gay no Brasil: o amor que não permite dizer o nome. 2001.

. “A revolução homossexual: o poder de um mito". Revista da USP, n. 49 (Dossiê Política \& Participação), p. 40-59, 2001.

- Sobre Candomblé e homossexualidade. Entrevista para G Magazine. Disponível em http://geocities.yahoo.com.br/luizmottbr/entre6.html. Acesso em 2008.

NIETO, José Antonio. Transexualidad, transgenerismo y cultura: antropología, identidad y género. Madrid, Talasa Ediciones, 1998.

ROBERTS, Nickie. As Prostitutas na História, Rio de Janeiro: Record/Rosa dos Tempos, 1998, 434 págs.

PATEMAN, C. O contrato sexual. Rio de Janeiro: Paz e Terra, 1993.

FIGUEIREDO \& PEIXOTO. Profissionais do sexo e vulnerabilidade - Sex professionals and vulnerability. Boletim do Instituto de Saúde - BIS. Volume $12-N^{o} 2$ - Agosto 2010. ISSN 15181812 / On Line 1809-7529. Janeiro: UERJ/IMS; 2001. p. 196 - 201.

PIRES, M. F. C. Education and the historical and dialectical materialism. Interface Comunicação, Saúde, Educação, v.1, n.1, 1997.

RANIERI, J. J. (Expositor); III Conferencia Internacional: La obra de Carlos Marx y los Desafios del Siglo XXI, Oral: Alienação e estranhamento. Período de 03/05/2006 a 06/05/2006, Havana, CUBA. 
ROSE, Gillian. Feminism \& Geography. The limits of Geographical Knowledge. Cambridge: Polity Press, 1993. p.205.

SAFFIOTI, Heleieth I.B.; ALMEIDA, Suely de Souza. Violência de gênero: poder e impotência. Rio de Janeiro, Revinter, 1995.

SAMOSATA. L., Diálogo das Cortesãs. 181 d.C.

SHAIKH, A. Exército industrial de reserva. In: BOTTOMORE, T. Dicionário do pensamento marxista. Rio de Janeiro: Jorge Zahar, 1988. p. 144.

SILVA, Hélio R. S. Travestis: entre o espelho e a rua. Rio de Janeiro: Rocco, 2007. (Gênero Plural).

SPENCER, Colin. Homossexualidade: avestis que realizam "ponto", que estavam a esperam de clientes.

TEIXEIRA RODRIGUES, Marlene. A prostituição no Brasil contemporâneo: um trabalho como outro qualquer? Revista Katálysis, vol.12 no.1 Florianópolis jan./jun. 2009. 


\section{ANEXOS}

\subsection{ROTEIRO DE ENTREVISTA}

Roteiro para realização de pesquisa de campo.

Trabalho de Conclusão de Curso Serviço Social - TCC

Cinthya Barroso de Sousa

BLOCO I - IDENTIFICAÇÃO/CARACTERÍSTICAS INICIAIS.

1. Nome/Nome de guerra:

2. Performance de gênero:

( ) Travesti ( ) Transexual ( ) Transgênero

3. Idade:

\section{BLOCO II - APROFUNDAMENTO.}

1. Há quanto tempo se prostitui?

2. Quais os locais onde se prostitui?

3. Considera a prostituição um trabalho ou exploração? [Você se enxerga como trabalhadora ou como explorada?] Detalhar para ambas as respostas. 